\title{
The Analysis of Limited Russian and North European Corporate Governance Standards after Global Crisis, Corporate Scandals and Market Manipulation
}

Author: $\quad$ Dinh Tran Ngoc Huy, Banking University, HCM city, Viet Nam - Graduate School of International Management, International University of Japan, Niigata, Japan, dtnhuy2010@gmail.com

This paper mainly analyzes principles and standards of some international and North European corporate governance frameworks which are issued during or after the global crisis.

First, it looks at the United Nation Good corporate governance practices and analyzes its strengths and impacts on corporate governance model of a company.

Second, it compared the UN standards to generally accepted governance standards of Sovereign Wealth Funds. The paper finds out that during the global crisis time 207-2008, despite taking care of risk management, there still lacks of certain governance standards in these 2 Codes. The, it analyzes some relative good corporate governance standards in Russia and a few North European countries including: Norway and Finland.

Third, this paper provides with a short summary of evaluation of these above 2 corporate governance principles in 2 groups which can enable corporations to compare to their current codes.

Last but not least, it aims to realize a limited general set of standards of corporate governance and give proper recommendations to relevant governments and organizations. Additionally, it includes a section for recommending corporate governance for developing countries including Viet Nam.

Keywords: corporate governance standards; board structure; code of best practice; financial crisis; corporate scandals; market manipulation; internal audit

JEL Classification: Goo, G3, G30 


\section{Introduction}

There are, in fact, three (3) main periods which are signaling the improvements made in the worldwide countries' corporate governance policies. The first period is the time during 1999-2003 after the Asian financial crisis taking place in 1997-1998, the second period is years from 2005-2008, and the third period is the current time, after the financial crisis 2007-2009 with impacts from US and Europe large economies. OECD and ICGN also offered good recommendations on corporate governance standards for most of countries in the world. This research paper is trying to take an implementation - oriented writing style and focus on some international corporate governance practices and issues during and after impacts from scandals and crises. They are United Nation (UN) and Sovereign Wealth Funds (SWF) governance practices in 2006 and 2008. Furthermore, The Norwegian Code 2010 also tried to provide good corporate governance to enhance confidence in companies.

Besides, this research paper aims to provide a writing style to adapt to an understandable reading to most of readers in academic field who is both familiar and not familiar to the corporate governance subject.

\section{Research literature review}

Until now, there are many researches in corporate governance field. Berle and Means (1932) identified that the problem of governance of managers comes from the ownership separation to a disciplinary function and a decisionmaking function. The Russian Code (2002) stated corporate governance influences economic entities and their ability to attract capital. Cremers and Nairs (2003) finds external governance, i.e., market of corporate control, and internal governance, i.e., shareholder monitoring, are strong complements. Gerard Chareaux (2004) said the objective of corporate governance theory is not about how managers govern, but about how they are governed. Malek Lashgari (2004) mentions corporate governance is concerned with managing the relationship among various corporate stakeholders, and common stockholders have the right to elect members of the Board. Abu-Tapanjeh (2008) pointed corporate governance has different meaning to different organizations. Li Wei An (2008) in a research of corporate governance said it is urgent matter to seek which governance model is more suitable for the governance environment where Chinese listed companies survive. Haslinda., \& Benedict (2009) stated 
the corporate governance theory began with agency theory, transaction cost and ethics related theories.

As Kirkpatrick, Grant., (2009) pointed out that even OECD corporate governance, short-called CG, principles needed to be review in key areas, including boar composition and competencies, remuneration issues, etc., after the financial crisis. Lambert, Caroline., and Sponem, Samuel., (2010) research in France with a conclusion that management controllers play an important role in profit manipulation and the shareholder pressure influence the nature of the management controller's task such as reporting and budgetary control. Last but not least, Thomas Wuil Joo (2010) explains "corporate governance" is mainly concern the internal governance of corporation, i.e., the relationship among participants in the enterprise.

A short summary or evaluation of a few global governance Codes has not been done yet.

\section{Theory of Corporate Governance, Scandal and Market Manipulation}

\section{Theory of manipulation}

Aggarwal, Rajesh K., Wu, Guonzu (2003) found out that potential manipulators can be corporate insiders, brokers, underwriters, large shareholders and market makers and stock prices rise throughout the manipulation period, prices higher when liquidity greater, and then fall in the post-manipulation period despite unclear evidence. They found that in a market with manipulators, more information seekers make $\backslash$ it easier for a manipulator to enter the market and potentially worsen the market efficiency.

Besides, Mei, Jianping., Wu, Guojun., and Zhou, Chunsheng (2004) shown the manipulator is a large investor who is a price setter, rather than a price taker. He or she can pump the stock price by a series of buying orders, then, dumps the stock to make profit.

\section{Theory of corporate governance and financial crisis}

For simplicity, corporate governance is a set of processes, customs and policies, rules directing and controlling an organization. Allen, Franklin., and Gale, Douglas., (2002) identify that Good corporate governance in US and UK means firms pursuing the shareholders' interests while it involves pursuing the interests of all company's stakeholders including customers and employee as 
well as shareholders, in Japan, France and Germany.

Moreover, Grant Kirkpatrick (2009) states in the OECD CG report that the financial crisis, for example 2007-2009, can be an important factor to failures of the CG system and the OECD CG principles need to be reviewed.

\section{Theory of Corporate scandals}

Cadette (2002), Madrick (2003) and Schwartz (2003) indicate that to gaudy earnings, options created outrage when top management or executives allow manipulation on quarterly report, resulted in short-term movements in stock prices, allowing sizeable personal profits despite probable future restatements of company earnings. In scandal examples of Enron, Qwest, many executives sold their stock when its price is high, while employees could not do so, because of access to privileged performance information.

Hence, corporate scandals may derive partially from false actions or manipulations of management or executives. In the scandal examples of Xerox or Worldcom, false accounting practices were taken into account when recognizing booking earnings for counterfeit transactions. Or in the case of Arthur Andersen, one of the Big Five, the auditing technique and procedures and professional responsibilities are main issues which cause failures in auditing Enron Corp which is filed for bankruptcy in 2001.

\section{Research methodology}

First, we select 2 international corporate governance practices including: 1) UN governance standards; and 2) SWF governance practices; we call this is group 1 .

We also use international standards of corporate governance for reference such as: OECD and ICGN's corporate governance principles and standards.

Then, we choose Norway, Finland and Russia which are representative for a limited North European group to analyze these countries' governance standards. We call this is group 2 "a relative group".

Second, we perform a qualitative analysis on each group code, then build general standards for corporate governance in two (2) above groups. These standards represent common understanding and principles in each group.

Third, we compare and provide a short summary of evaluation of the 
2 groups' standards.

Finally, we make a suggestion on what so-called a short general corporate governance principles for Russia and a few North European nations. Additionally, it can be considered as the recommendation to relevant countries' government and other relevant organizations for further steps, public policy and necessary evaluation.

\section{Empirical findings}

A- Findings on Corporate governance issues after financial crisis, corporate scandals and market manipulation

First of all, we found out that there is a lack of code of ethics or code of conduct.

The second important corporate governance issue is that the corporate governance mechanisms is not complete and perfect in the aspect that some codes mention mainly certain sides of governance such as disclosure and omit other sides.

Third, in the company, who has the right and how to prevent and control the manipulation actions which may come from either manipulators or executives and management team.

Last but not least, one major corporate governance issue exsiting as the main cause to corporate scandals of these companies is that who are qualified board members or management team members.

\section{B-Findings on Ways of Manipulation during Corporate Scandals} Several Manipulation Techniques found out during corporate scandals involve, but not limit to:

\section{B.1 - The manipulation techniques in the income statement:}

The use of inappropriate companies to inflate the company's revenues with a hope to inflate the company's stock price is done by a family corporation such as Adelphia in the late 1990s, which leads to its collapse in 2002. Another case, Livedoor co. in Japan, shows us that the management cooks its book and transfer profits from its consumer - related firm; so, the firm has earnings, not loss, and manipulate stock price.

B.2 - The manipulation techniques in both the income statement and balance sheet:

The technique is used by the famous company in Japan, Xerox, in 
the year 2001-2002. It manipulates its revenues or earnings by inappropriately classifying equipment rentals as long -term leases, by which it could accelerate the revenues instead of spreading out the rent. By manipulating its earnings, Xerox overstated its revenues up to \$2 billion. During the period 1997-1999, the firm has experienced the effect of the manipulation while its stock price increased up to a peak of $\$ 60$ per share, then, falling down.

B.3-The manipulation techniques relevant to international accounting practice code:

We can refer here the case of Nortel Co. in Canada, in which the co. has violated the Canadian GAAP and changed its revenues recognizing policy. This helps the firm to manipulate its books. It also violated the Principle of Conservatism of GAAP by overstating the post-dot com earnings.

B.4- The manipulation techniques not relevant to all the above:

We can refer here the famous case of AOL Time Warner fraud, in which the top executives of the firm used the money of the corporation for affecting stock price collapse, i.e., trick transactions, and then get large benefits by liquidating their shares in 2000-2001.

\section{C- Findings on Actions to Prevent or Control Negative Market Manipulation}

Among proper actions to prevent and control negative market manipulation is taking from the example of Olympus Co. in Japan. This case shows us that if the firm has had the qualified internal auditing, it could avoid the accounting fraud.

Moreover, The Corporation, generally, might consider changing its management team or executives. Once the management cooks its books and reports inappropriate profit figures, the team can be replaced. Last but not least, the company might consider using GAAP principles of recognizing revenues or of conservatism, and of recognizing long-term leases for avoiding negative manipulation in accounting and in the stock market.

\section{D- Findings on Construction of a Limited General Corporate Governance standards \\ These findings will be shown in a detailed analysis of a model indicated in the later sessions. \\ $<$ D.1> - Group 1 - Some International Corporate Governance standards $<a>$ The United Nation governance standards analysis}


One of major different features in the 2006 UN Code is that it identified independent leadership of Board of management and focus on many aspects of information disclosure.

Besides, the Code emphasizes the two tier system of the Board organization including Board of management and Board of supervisory.

Additionally, The Code pays a lot of attention on disclosure roles and functions of the Board, which forms a new term "corporate governance disclosure".

Table D.o: United Nation Corporate Governance general standards (a short summary evaluation)

\begin{tabular}{|c|c|c|c|c|c|}
\hline $\begin{array}{l}\text { Subjects } \\
\text { or parties }\end{array}$ & $\begin{array}{l}\text { Main qual- } \\
\text { ity factors }\end{array}$ & $\begin{array}{l}\text { Sub quality } \\
\text { factors }\end{array}$ & Responsibilities & Objectives & Note \\
\hline $\begin{array}{l}\text { Audit } \\
\text { commit- } \\
\text { tee }\end{array}$ & $\begin{array}{l}\text { Not } \\
\text { mentioned } \\
\text { clearly in } \\
\text { the Code }\end{array}$ & $\begin{array}{l}\text { Vary depends } \\
\text { on size, com- } \\
\text { plexity of the } \\
\text { firm; }\end{array}$ & $\begin{array}{l}\text { Review fair value } \\
\text { computation; Can be } \\
\text { used for preparatory } \\
\text { work of the Board; }\end{array}$ & $\begin{array}{l}\text { In conjunc- } \\
\text { tion with } \\
\text { internal } \\
\text { audit; }\end{array}$ & $\begin{array}{l}\text { From } \\
\text { the } \\
\text { Code; }\end{array}$ \\
\hline $\begin{array}{l}\text { Nomina- } \\
\text { tion com- } \\
\text { mittee }\end{array}$ & $\begin{array}{l}\text { Not } \\
\text { mentioned } \\
\text { clearly in } \\
\text { the Code }\end{array}$ & $\begin{array}{l}\text { Not men- } \\
\text { tioned clearly } \\
\text { in the Code }\end{array}$ & $\begin{array}{l}\text { Use external advisers } \\
\text { to find new direc- } \\
\text { tors; Can be used for } \\
\text { preparatory work of } \\
\text { the Board; }\end{array}$ & $\begin{array}{l}\text { Not } \\
\text { mentioned } \\
\text { clearly in } \\
\text { the Code }\end{array}$ & $\begin{array}{l}\text { From } \\
\text { the } \\
\text { Code; }\end{array}$ \\
\hline $\begin{array}{l}\text { Compen- } \\
\text { sation or } \\
\text { Remu- } \\
\text { neration } \\
\text { commit- } \\
\text { tee }\end{array}$ & $\begin{array}{l}\text { Not } \\
\text { mentioned } \\
\text { clearly in } \\
\text { the Code }\end{array}$ & $\begin{array}{l}\text { Clear distinc- } \\
\text { tion b.t } \\
\text { Executive and } \\
\text { Non-ex direc- } \\
\text { tors; }\end{array}$ & $\begin{array}{l}\text { Can be used for pre- } \\
\text { paratory work of the } \\
\text { Board; }\end{array}$ & $\begin{array}{l}\text { Not } \\
\text { mentioned } \\
\text { clearly in } \\
\text { the Code }\end{array}$ & $\begin{array}{l}\text { From } \\
\text { the } \\
\text { Code; }\end{array}$ \\
\hline CEO & $\begin{array}{l}\text { Not } \\
\text { mentioned } \\
\text { clearly in } \\
\text { the Code }\end{array}$ & $\begin{array}{l}\text { Not men- } \\
\text { tioned clearly } \\
\text { in the Code }\end{array}$ & $\begin{array}{l}\text { Roles can be com- } \\
\text { bined with those of } \\
\text { the chair; }\end{array}$ & $\begin{array}{l}\text { Not } \\
\text { mentioned } \\
\text { clearly in } \\
\text { the Code }\end{array}$ & $\begin{array}{l}\text { From } \\
\text { the } \\
\text { Code; }\end{array}$ \\
\hline The Chair & $\begin{array}{l}\text { Not } \\
\text { mentioned } \\
\text { clearly in } \\
\text { the Code }\end{array}$ & $\begin{array}{l}\text { Not men- } \\
\text { tioned clearly } \\
\text { in the Code }\end{array}$ & $\begin{array}{l}\text { Roles can be com- } \\
\text { bined with those of } \\
\text { the CEO; }\end{array}$ & $\begin{array}{l}\text { Not } \\
\text { mentioned } \\
\text { clearly in } \\
\text { the Code }\end{array}$ & \\
\hline $\begin{array}{l}\text { CEO and } \\
\text { The Chair } \\
\text { relation- } \\
\text { ship }\end{array}$ & $\begin{array}{l}\text { Not } \\
\text { mentioned } \\
\text { clearly in } \\
\text { the Code }\end{array}$ & $\begin{array}{l}\text { Not men- } \\
\text { tioned clearly } \\
\text { in the Code }\end{array}$ & $\begin{array}{l}\text { Roles can be com- } \\
\text { bined; }\end{array}$ & $\begin{array}{l}\text { Not } \\
\text { mentioned } \\
\text { clearly in } \\
\text { the Code }\end{array}$ & \\
\hline
\end{tabular}




\begin{tabular}{|c|c|c|c|c|c|}
\hline $\begin{array}{l}\text { Corporate } \\
\text { Secretary }\end{array}$ & $\begin{array}{l}\text { Not } \\
\text { mentioned } \\
\text { clearly in } \\
\text { the Code }\end{array}$ & $\begin{array}{l}\text { Not men- } \\
\text { tioned clearly } \\
\text { in the Code }\end{array}$ & $\begin{array}{l}\text { Not mentioned } \\
\text { clearly in the Code }\end{array}$ & $\begin{array}{l}\text { Not } \\
\text { mentioned } \\
\text { clearly in } \\
\text { the Code }\end{array}$ & \\
\hline $\begin{array}{l}\text { Compli- } \\
\text { ance } \\
\text { officer }\end{array}$ & $\begin{array}{l}\text { Not } \\
\text { mentioned } \\
\text { clearly in } \\
\text { the Code }\end{array}$ & $\begin{array}{l}\text { "Comply } \\
\text { or explain" } \\
\text { mechanism; }\end{array}$ & $\begin{array}{l}\text { Not mentioned } \\
\text { clearly in the Code }\end{array}$ & $\begin{array}{l}\text { Greater in- } \\
\text { formation } \\
\text { access to } \\
\text { stakehold- } \\
\text { ers; }\end{array}$ & \\
\hline $\begin{array}{l}\text { Board of } \\
\text { Directors }\end{array}$ & $\begin{array}{l}\text { Two tier } \\
\text { system; } \\
\text { Executive } \\
\text { and Non- ex } \\
\text { directors; }\end{array}$ & $\begin{array}{l}\text { Disclose high } \\
\text { quality infor- } \\
\text { mation of BD } \\
\text { on financial } \\
\text { results; }\end{array}$ & $\begin{array}{l}\text { Clearly identify inher- } \\
\text { ent risks; review fair } \\
\text { value computation; } \\
\text { oversee the process } \\
\text { of F.S; }\end{array}$ & $\begin{array}{l}\text { Not } \\
\text { mentioned } \\
\text { clearly in } \\
\text { the Code }\end{array}$ & \\
\hline $\begin{array}{l}\text { Executive } \\
\text { director }\end{array}$ & $\begin{array}{l}\text { Not } \\
\text { mentioned } \\
\text { clearly in } \\
\text { the Code }\end{array}$ & $\begin{array}{l}\text { Composed of } \\
\text { the Board; }\end{array}$ & $\begin{array}{l}\text { Attend committee } \\
\text { and Board meetings; }\end{array}$ & $\begin{array}{l}\text { Not } \\
\text { mentioned } \\
\text { clearly in } \\
\text { the Code } \\
\end{array}$ & \\
\hline $\begin{array}{l}\text { Non- } \\
\text { executive } \\
\text { director }\end{array}$ & $\begin{array}{l}\text { Not } \\
\text { mentioned } \\
\text { clearly in } \\
\text { the Code } \\
\end{array}$ & $\begin{array}{l}\text { Not all are } \\
\text { independent } \\
\text { directors; }\end{array}$ & $\begin{array}{l}\text { Attend committee } \\
\text { and Board meetings; } \\
\text { Some can join Board } \\
\text { committees; }\end{array}$ & $\begin{array}{l}\text { Not } \\
\text { mentioned } \\
\text { clearly in } \\
\text { the Code } \\
\end{array}$ & \\
\hline $\begin{array}{l}\text { Inde- } \\
\text { pendent } \\
\text { director }\end{array}$ & $\begin{array}{l}\text { Not } \\
\text { mentioned } \\
\text { clearly in } \\
\text { the Code }\end{array}$ & $\begin{array}{l}\text { Not men- } \\
\text { tioned clearly } \\
\text { in the Japan } \\
\text { Code }\end{array}$ & $\begin{array}{l}\text { Can have greater } \\
\text { importance; Attend } \\
\text { committee and Board } \\
\text { meetings; }\end{array}$ & $\begin{array}{l}\text { Not } \\
\text { mentioned } \\
\text { clearly in } \\
\text { the Code } \\
\end{array}$ & $\begin{array}{l}\text { From } \\
\text { the } \\
\text { Code; }\end{array}$ \\
\hline CFO & $\begin{array}{l}\text { Not } \\
\text { mentioned } \\
\text { clearly in } \\
\text { the Code }\end{array}$ & $\begin{array}{l}\text { Not men- } \\
\text { tioned clearly } \\
\text { in the Code }\end{array}$ & $\begin{array}{l}\text { Not mentioned } \\
\text { clearly in the Code }\end{array}$ & $\begin{array}{l}\text { Not } \\
\text { mentioned } \\
\text { clearly in } \\
\text { the Code } \\
\end{array}$ & \\
\hline $\begin{array}{l}\text { Manage- } \\
\text { ment } \\
\text { team }\end{array}$ & $\begin{array}{l}\text { Independ- } \\
\text { ent leader- } \\
\text { ship; }\end{array}$ & $\begin{array}{l}\text { Not men- } \\
\text { tioned clearly } \\
\text { in the Code }\end{array}$ & $\begin{array}{l}\text { Disclose material } \\
\text { interests, approval } \\
\text { process of related } \\
\text { party transactions; } \\
\text { have executive re- } \\
\text { sponsibilities; }\end{array}$ & $\begin{array}{l}\text { Financial } \\
\text { and op- } \\
\text { erational } \\
\text { results; }\end{array}$ & $\begin{array}{l}\text { Under- } \\
\text { stood } \\
\text { from } \\
\text { the } \\
\text { Code; }\end{array}$ \\
\hline $\begin{array}{l}\text { Super- } \\
\text { visory } \\
\text { board }\end{array}$ & $\begin{array}{l}\text { Not } \\
\text { mentioned } \\
\text { clearly in } \\
\text { the Code }\end{array}$ & $\begin{array}{l}\text { Can be } \\
\text { independ- } \\
\text { ent external } \\
\text { advisers; }\end{array}$ & $\begin{array}{l}\text { Monitoring and } \\
\text { supervision of the } \\
\text { company's manage- } \\
\text { ment; } \\
\text { Strategic direction } \\
\text { of the company; } \\
\text { Enhance directors' } \\
\text { ability to fulfill duties; }\end{array}$ & $\begin{array}{l}\text { Support } \\
\text { the struc- } \\
\text { ture, roles } \\
\text { of govern- } \\
\text { ance; }\end{array}$ & $\begin{array}{l}\text { From } \\
\text { the } \\
\text { code; }\end{array}$ \\
\hline
\end{tabular}




\begin{tabular}{|c|c|c|c|c|}
\hline $\begin{array}{l}\text { Internal } \\
\text { control }\end{array}$ & $\begin{array}{l}\text { Not } \\
\text { mentioned } \\
\text { clearly in } \\
\text { the Code }\end{array}$ & $\begin{array}{l}\text { Not men- } \\
\text { tioned clearly } \\
\text { in the Code }\end{array}$ & $\begin{array}{l}\text { Used by The Board to } \\
\text { mitigate risks; }\end{array}$ & $\begin{array}{l}\text { Risk man- } \\
\text { agement } \\
\text { objectives; }\end{array}$ \\
\hline $\begin{array}{l}\text { Internal } \\
\text { audit (I.A) }\end{array}$ & $\begin{array}{l}\text { Not } \\
\text { mentioned } \\
\text { clearly in } \\
\text { the Code }\end{array}$ & Effective; & $\begin{array}{l}\text { Board determines } \\
\text { scope and duties of } \\
\text { I.A; }\end{array}$ & $\begin{array}{l}\text { Report to } \\
\text { the high- } \\
\text { est level of } \\
\text { leadership } \\
\text { of the en- } \\
\text { terprise; }\end{array}$ \\
\hline $\begin{array}{l}\text { External } \\
\text { audit }\end{array}$ & $\begin{array}{l}\text { Independ- } \\
\text { ence; } \\
\text { Integrity; } \\
\text { Compe- } \\
\text { tency; }\end{array}$ & $\begin{array}{l}\text { Duration } \\
\text { of current } \\
\text { auditors; } \\
\text { Avoid interest } \\
\text { conflicts in } \\
\text { non-audit } \\
\text { services; }\end{array}$ & $\begin{array}{l}\text { Audit works and non- } \\
\text { audit works; fees paid } \\
\text { for non-audit works; }\end{array}$ & $\begin{array}{l}\text { Provide } \\
\text { objective } \\
\text { assurance } \\
\text { on F.S; }\end{array}$ \\
\hline $\begin{array}{l}\text { Disclo- } \\
\text { sure and } \\
\text { transpar- } \\
\text { ency }\end{array}$ & $\begin{array}{l}\text { How } \\
\text { sharehold- } \\
\text { ers exercise } \\
\text { their con- } \\
\text { trol rights; } \\
\text { Control } \\
\text { structure; } \\
\text { comprehen- } \\
\text { sive }\end{array}$ & $\begin{array}{l}\text { Nature, type } \\
\text { and elements } \\
\text { of related- } \\
\text { party transac- } \\
\text { tions; }\end{array}$ & $\begin{array}{l}\text { Consolidation re- } \\
\text { quirements on F.S are } \\
\text { conducted; Disclose } \\
\text { significant relate- } \\
\text { party transactions; } \\
\text { procedures of M\&A; }\end{array}$ & $\begin{array}{l}\text { Equality of } \\
\text { disclosure; } \\
\text { "substance } \\
\text { over } \\
\text { form"; }\end{array}$ \\
\hline $\begin{array}{l}\text { Share- } \\
\text { holders } \\
\text { and } \\
\text { Minor- } \\
\text { ity Stock- } \\
\text { holder }\end{array}$ & $\begin{array}{l}\text { One share } \\
\text { one vote; }\end{array}$ & $\begin{array}{l}\text { Equitable } \\
\text { treatment of } \\
\text { shareholders }\end{array}$ & $\begin{array}{l}\text { Aware of type, } \\
\text { number, duties of } \\
\text { outside management } \\
\text { positions held by indi- } \\
\text { vidual director; Judge } \\
\text { ability of directors; }\end{array}$ & $\begin{array}{l}\text { Not } \\
\text { mentioned } \\
\text { clearly in } \\
\text { the Code }\end{array}$ \\
\hline $\begin{array}{l}\text { Financial } \\
\text { reporting } \\
\text { standards }\end{array}$ & $\begin{array}{l}\text { Used In- } \\
\text { ternational } \\
\text { Financial } \\
\text { Reporting } \\
\text { Standards } \\
\text { (IFRs); true } \\
\text { and fair } \\
\text { view; }\end{array}$ & $\begin{array}{l}\text { Based on } \\
\text { generally } \\
\text { accepted ac- } \\
\text { counting } \\
\text { principles; }\end{array}$ & $\begin{array}{l}\text { BD gives further } \\
\text { explanations in MDA } \\
\text { section; }\end{array}$ & $\begin{array}{l}\text { Appro- } \\
\text { priately } \\
\text { followed; }\end{array}$ \\
\hline Employee & $\begin{array}{l}\text { Not } \\
\text { mentioned } \\
\text { clearly in } \\
\text { the Code }\end{array}$ & $\begin{array}{l}\text { Disclose } \\
\text { employee } \\
\text { involvement }\end{array}$ & $\begin{array}{l}\text { Can elect supervisory } \\
\text { Board; or nominate } \\
\text { directors; }\end{array}$ & $\begin{array}{l}\text { Not } \\
\text { mentioned } \\
\text { clearly in } \\
\text { the Code }\end{array}$ \\
\hline
\end{tabular}




\begin{tabular}{|l|l|}
\hline Note & $\begin{array}{l}\text { The underlined part is describing some more works needed to be done for } \\
\text { relevant subjects and parties. MDA means Management Discussion and } \\
\text { Analysis }\end{array}$ \\
\hline
\end{tabular}

\section{$<$ b $>$ SWF governance standards analysis}

In Oct 2008, SWF or Santiago (Chile) principles of governance were published after the meeting of 26 IMF country members. They agree on generally accepted principles and practices (GAPP).

Besides, the 2008 SWF Code points the needed disclosure of legal relationship b.t SWF and bodies such as central bank, other enterprises.

Additionally, The SWF governance principles had paid attention to the organization of SWF (funds) and relevant public disclosure.

Despite of more details in investment governance, the SWF principles cover limited issues, compared to the UN Code.

Table D.1: SWF Corporate Governance general standards (a short summary evaluation)

\begin{tabular}{|l|l|l|l|l|l|}
\hline $\begin{array}{l}\text { Subjects } \\
\text { or parties }\end{array}$ & $\begin{array}{l}\text { Main qual- } \\
\text { ity factors }\end{array}$ & $\begin{array}{l}\text { Sub quality } \\
\text { factors }\end{array}$ & Responsibilities & Objectives & Note \\
\hline $\begin{array}{l}\text { Audit } \\
\text { committee } \\
\text { mentioned } \\
\text { thearly in } \\
\text { mede } \\
\text { clearly in } \\
\text { the Code }\end{array}$ & $\begin{array}{l}\text { Not } \\
\text { mot } \\
\text { structure; }\end{array}$ & $\begin{array}{l}\text { Might be included } \\
\text { in governance } \\
\text { oversight, deci- } \\
\text { sion making, and } \\
\text { operational } \\
\text { responsibilities; }\end{array}$ & $\begin{array}{l}\text { appropriate and } \\
\text { the } \\
\text { Code; } \\
\text { from }\end{array}$ & $\begin{array}{l}\text { Under- } \\
\text { stood }\end{array}$ \\
\hline $\begin{array}{l}\text { Nomina- } \\
\text { tion com- } \\
\text { mittee }\end{array}$ & $\begin{array}{l}\text { Not } \\
\text { mentioned } \\
\text { clearly in } \\
\text { the Code } \\
\text { mentioned } \\
\text { clearly in } \\
\text { the Code }\end{array}$ & $\begin{array}{l}\text { in the governance } \\
\text { structure; }\end{array}$ & $\begin{array}{l}\text { appropriate and } \\
\text { effective division } \\
\text { of } \\
\text { oversight, deci- } \\
\text { sion making, and } \\
\text { operational } \\
\text { responsibilities; }\end{array}$ & $\begin{array}{l}\text { Under- } \\
\text { stood } \\
\text { From } \\
\text { Code; }\end{array}$ \\
\hline $\begin{array}{l}\text { Compen- } \\
\text { sation or } \\
\text { Remu- } \\
\text { neration } \\
\text { committee }\end{array}$ & $\begin{array}{l}\text { Not } \\
\text { mentioned } \\
\text { clearly in } \\
\text { the Code }\end{array}$ & $\begin{array}{l}\text { Compensa- } \\
\text { tion frame- } \\
\text { work; }\end{array}$ & $\begin{array}{l}\text { Might be included } \\
\text { in the governance } \\
\text { structure; }\end{array}$ & $\begin{array}{l}\text { Sustainable long } \\
\text { term value crea- } \\
\text { tion; }\end{array}$ & $\begin{array}{l}\text { Under- } \\
\text { stood } \\
\text { From } \\
\text { the } \\
\text { Code; }\end{array}$ \\
\hline
\end{tabular}




\begin{tabular}{|c|c|c|c|c|c|}
\hline CEO & $\begin{array}{l}\text { appro- } \\
\text { priately } \\
\text { qualified } \\
\text { and well- } \\
\text { trained; }\end{array}$ & $\begin{array}{l}\text { Profession- } \\
\text { al ethical } \\
\text { standards; }\end{array}$ & $\begin{array}{l}\text { Code of conduct } \\
\text { formed; act in the } \\
\text { best interests of } \\
\text { SWF; can be ap- } \\
\text { pointed/ removed } \\
\text { by governing } \\
\text { bodies; }\end{array}$ & $\begin{array}{l}\text { Not mentioned } \\
\text { clearly in the } \\
\text { Code }\end{array}$ & \\
\hline The Chair & $\begin{array}{l}\text { Profes- } \\
\text { sional } \\
\text { ethical } \\
\text { standards; }\end{array}$ & $\begin{array}{l}\text { Can be sup- } \\
\text { ported by } \\
\text { Vice Chair- } \\
\text { man; }\end{array}$ & $\begin{array}{l}\text { Code of conduct } \\
\text { formed; }\end{array}$ & $\begin{array}{l}\text { Not mentioned } \\
\text { clearly in the } \\
\text { Code }\end{array}$ & \\
\hline $\begin{array}{l}\text { CEO and } \\
\text { The Chair } \\
\text { relation- } \\
\text { ship }\end{array}$ & $\begin{array}{l}\text { Not } \\
\text { mentioned } \\
\text { clearly in } \\
\text { the Code }\end{array}$ & $\begin{array}{l}\text { Not } \\
\text { mentioned } \\
\text { clearly in } \\
\text { the Code }\end{array}$ & $\begin{array}{l}\text { Not mentioned } \\
\text { clearly in the Code }\end{array}$ & $\begin{array}{l}\text { Not mentioned } \\
\text { clearly in the } \\
\text { Code }\end{array}$ & \\
\hline $\begin{array}{l}\text { Corporate } \\
\text { Secretary }\end{array}$ & $\begin{array}{l}\text { Not } \\
\text { mentioned } \\
\text { clearly in } \\
\text { the Code }\end{array}$ & $\begin{array}{l}\text { Not } \\
\text { mentioned } \\
\text { clearly in } \\
\text { the Japan } \\
\text { Code }\end{array}$ & $\begin{array}{l}\text { Not mentioned } \\
\text { clearly in the Code }\end{array}$ & $\begin{array}{l}\text { Not mentioned } \\
\text { clearly in the } \\
\text { Code }\end{array}$ & \\
\hline $\begin{array}{l}\text { Compli- } \\
\text { ance } \\
\text { officer }\end{array}$ & $\begin{array}{l}\text { Sound le- } \\
\text { gal frame- } \\
\text { work; }\end{array}$ & $\begin{array}{l}\text { Consist- } \\
\text { ent with } \\
\text { applicable } \\
\text { laws; }\end{array}$ & $\begin{array}{l}\text { SWF establishment } \\
\text { clearly authorized } \\
\text { under domestic } \\
\text { law; forming legal } \\
\text { division; }\end{array}$ & $\begin{array}{l}\text { Not mentioned } \\
\text { clearly in the } \\
\text { Code }\end{array}$ & $\begin{array}{l}\text { From } \\
\text { the } \\
\text { Code; }\end{array}$ \\
\hline $\begin{array}{l}\text { Board of } \\
\text { Directors }\end{array}$ & $\begin{array}{l}\text { appro- } \\
\text { priately } \\
\text { qualified } \\
\text { and well- } \\
\text { trained; }\end{array}$ & $\begin{array}{l}\text { Profession- } \\
\text { al ethical } \\
\text { standards; }\end{array}$ & $\begin{array}{l}\text { Code of conduct } \\
\text { formed; act in the } \\
\text { best interests of } \\
\text { SWF; }\end{array}$ & $\begin{array}{l}\text { Accountability } \\
\text { and operational } \\
\text { independence; }\end{array}$ & \\
\hline $\begin{array}{l}\text { Executive } \\
\text { director }\end{array}$ & $\begin{array}{l}\text { Not } \\
\text { mentioned } \\
\text { clearly in } \\
\text { the Code }\end{array}$ & $\begin{array}{l}\text { May from } \\
\text { private sec- } \\
\text { tor; }\end{array}$ & $\begin{array}{l}\text { Not mentioned } \\
\text { clearly in the Code }\end{array}$ & $\begin{array}{l}\text { Not mentioned } \\
\text { clearly in the } \\
\text { Code }\end{array}$ & $\begin{array}{l}\text { From } \\
\text { the } \\
\text { Code; }\end{array}$ \\
\hline $\begin{array}{l}\text { Non- } \\
\text { executive } \\
\text { director }\end{array}$ & $\begin{array}{l}\text { Not } \\
\text { mentioned } \\
\text { clearly in } \\
\text { the Code }\end{array}$ & $\begin{array}{l}\text { May from } \\
\text { private sec- } \\
\text { tor; }\end{array}$ & $\begin{array}{l}\text { Not mentioned } \\
\text { clearly in the Code }\end{array}$ & $\begin{array}{l}\text { Not mentioned } \\
\text { clearly in the } \\
\text { Code }\end{array}$ & \\
\hline $\begin{array}{l}\text { Independ- } \\
\text { ent direc- } \\
\text { tor }\end{array}$ & $\begin{array}{l}\text { Not } \\
\text { mentioned } \\
\text { clearly in } \\
\text { the Code }\end{array}$ & $\begin{array}{l}\text { May from } \\
\text { private sec- } \\
\text { tor; }\end{array}$ & $\begin{array}{l}\text { Not mentioned } \\
\text { clearly in the Code }\end{array}$ & $\begin{array}{l}\text { Not mentioned } \\
\text { clearly in the } \\
\text { Code }\end{array}$ & \\
\hline
\end{tabular}




\begin{tabular}{|c|c|c|c|c|c|}
\hline CFO & $\begin{array}{l}\text { Not } \\
\text { mentioned } \\
\text { clearly in } \\
\text { the Code }\end{array}$ & $\begin{array}{l}\text { Not } \\
\text { mentioned } \\
\text { clearly in } \\
\text { the Code }\end{array}$ & $\begin{array}{l}\text { Not mentioned } \\
\text { clearly in the Code }\end{array}$ & $\begin{array}{l}\text { Not mentioned } \\
\text { clearly in the } \\
\text { Code }\end{array}$ & \\
\hline $\begin{array}{l}\text { Manage- } \\
\text { ment } \\
\text { team }\end{array}$ & $\begin{array}{l}\text { appro- } \\
\text { priately } \\
\text { qualified } \\
\text { and well- } \\
\text { trained; } \\
\text { reputable, } \\
\text { creditwor- } \\
\text { thy; }\end{array}$ & $\begin{array}{l}\text { Profession- } \\
\text { al ethical } \\
\text { standards; } \\
\text { can be } \\
\text { external } \\
\text { managers; }\end{array}$ & $\begin{array}{l}\text { Code of conduct } \\
\text { formed; undertak- } \\
\text { ing investment } \\
\text { activities in special- } \\
\text { ized instruments } \\
\text { and markets; } \\
\text { reducing costs of } \\
\text { maintaining an } \\
\text { asset mgt. opera- } \\
\text { tion; act in the best } \\
\text { interests of SWF; }\end{array}$ & $\begin{array}{l}\text { Accountability } \\
\text { and operational } \\
\text { independence; }\end{array}$ & \\
\hline $\begin{array}{l}\text { Superviso- } \\
\text { ry board }\end{array}$ & $\begin{array}{l}\text { Not } \\
\text { mentioned } \\
\text { clearly in } \\
\text { the Code }\end{array}$ & $\begin{array}{l}\text { Can com- } \\
\text { pose of } \\
\text { govern- } \\
\text { ment au- } \\
\text { thorities; }\end{array}$ & $\begin{array}{l}\text { Form a governance } \\
\text { structure, together } \\
\text { with Board of } \\
\text { Directors and Man- } \\
\text { agement; }\end{array}$ & $\begin{array}{l}\text { Not mentioned } \\
\text { clearly in the } \\
\text { Code }\end{array}$ & \\
\hline $\begin{array}{l}\text { Internal } \\
\text { control }\end{array}$ & $\begin{array}{l}\text { Not } \\
\text { mentioned } \\
\text { clearly in } \\
\text { the Japan } \\
\text { Code }\end{array}$ & $\begin{array}{l}\text { A frame- } \\
\text { work to } \\
\text { identify } \\
\text { and man- } \\
\text { age risks; }\end{array}$ & $\begin{array}{l}\text { Identify risk bear- } \\
\text { ing capacity, risk } \\
\text { tolerance level; }\end{array}$ & $\begin{array}{l}\text { Adequate opera- } \\
\text { tional controls, } \\
\text { strong risk } \\
\text { management } \\
\text { culture; }\end{array}$ & $\begin{array}{l}\text { From } \\
\text { the } \\
\text { Code; }\end{array}$ \\
\hline $\begin{array}{l}\text { Internal } \\
\text { audit }\end{array}$ & $\begin{array}{l}\text { Not } \\
\text { mentioned } \\
\text { clearly in } \\
\text { the Code }\end{array}$ & $\begin{array}{l}\text { Independ- } \\
\text { ent audits; }\end{array}$ & $\begin{array}{l}\text { Audit internally } \\
\text { activities; }\end{array}$ & $\begin{array}{l}\text { Not mentioned } \\
\text { clearly in the } \\
\text { Code }\end{array}$ & \\
\hline $\begin{array}{l}\text { External } \\
\text { audit }\end{array}$ & $\begin{array}{l}\text { Not } \\
\text { mentioned } \\
\text { clearly in } \\
\text { the Code }\end{array}$ & $\begin{array}{l}\text { Inde- } \\
\text { pendent } \\
\text { commercial } \\
\text { auditor; }\end{array}$ & $\begin{array}{l}\text { Not mentioned } \\
\text { clearly in the Code }\end{array}$ & $\begin{array}{l}\text { Not mentioned } \\
\text { clearly in the } \\
\text { Code }\end{array}$ & $\begin{array}{l}\text { From } \\
\text { the } \\
\text { Code } \\
\text { and } \\
\text { appen- } \\
\text { dix; }\end{array}$ \\
\hline $\begin{array}{l}\text { Disclosure } \\
\text { and trans- } \\
\text { parency }\end{array}$ & $\begin{array}{l}\text { Not } \\
\text { mentioned } \\
\text { clearly in } \\
\text { the Code }\end{array}$ & $\begin{array}{l}\text { Not } \\
\text { mentioned } \\
\text { clearly in } \\
\text { the Code }\end{array}$ & $\begin{array}{l}\text { Publicly disclo- } \\
\text { sure of general } \\
\text { approaches to RM; } \\
\text { Disclose policy } \\
\text { purpose of SWF; } \\
\text { legal relationship } \\
\text { b.t SWF and state } \\
\text { bodies; }\end{array}$ & $\begin{array}{l}\text { Not mentioned } \\
\text { clearly in the } \\
\text { Code }\end{array}$ & \\
\hline
\end{tabular}




\begin{tabular}{|c|c|c|c|c|c|}
\hline $\begin{array}{l}\text { Sharehold- } \\
\text { ers and } \\
\text { Minority } \\
\text { Stockhold- } \\
\text { er }\end{array}$ & $\begin{array}{l}\text { Not } \\
\text { mentioned } \\
\text { clearly in } \\
\text { the Code }\end{array}$ & $\begin{array}{l}\text { Not } \\
\text { mentioned } \\
\text { clearly in } \\
\text { the Code }\end{array}$ & $\begin{array}{l}\text { Exercise their } \\
\text { ownership rights } \\
\text { to protect financial } \\
\text { value; }\end{array}$ & $\begin{array}{l}\text { Not mentioned } \\
\text { clearly in the } \\
\text { Code }\end{array}$ & \\
\hline $\begin{array}{l}\text { Financial } \\
\text { reporting } \\
\text { standards }\end{array}$ & $\begin{array}{l}\text { Audited } \\
\text { annually; }\end{array}$ & $\begin{array}{l}\text { In timely } \\
\text { fashion; }\end{array}$ & $\begin{array}{l}\text { Audited annually } \\
\text { complied with intl. } \\
\text { or national stand- } \\
\text { ards; }\end{array}$ & $\begin{array}{l}\text { Not mentioned } \\
\text { clearly in the } \\
\text { Code }\end{array}$ & \\
\hline Employee & $\begin{array}{l}\text { appro- } \\
\text { priately } \\
\text { qualified } \\
\text { and well- } \\
\text { trained; }\end{array}$ & $\begin{array}{l}\text { Profession- } \\
\text { al ethical } \\
\text { standards; }\end{array}$ & $\begin{array}{l}\text { Code of conduct } \\
\text { formed; }\end{array}$ & $\begin{array}{l}\text { Not mentioned } \\
\text { clearly in the } \\
\text { Code }\end{array}$ & \\
\hline Note & \multicolumn{5}{|c|}{$\begin{array}{l}\text { The underlined part is describing some more works needed to be done for } \\
\text { relevant subjects and parties. RM means Risk management. }\end{array}$} \\
\hline
\end{tabular}

\section{Comparison between UN and SWF Corporate governance standards}

Based on the above information, we can see the UN Code shows a lot of information on disclosure such as disclosure of Board and of selection of external auditors, as well as scope of work of internal audit function. While, the SWF Code, many times, confirm the roles of risk management and control activities in SWF.

Another advantage in the UN Code is the consideration of Internet voting in meetings of shareholders. The Code encourages some voting technologies.

Last but not least, one different point in The SWF Code, compared to the UN Code, is that it connects risk management functions with investment activities. It means that, the Code specifies roles of risk management in more details.

\section{The Establishment of so-called Limited International Corporate Governance standards}

With the selection of UN and SWF as two governance codes which represent in the construction of general corporate governance principles and standards, we build the below table with the following criteria:

Firstly, it should have some attributes which enable the corporation or its Board to share and disclose better information with its stakeholders and shareholders. 


\section{Secondly, it focuses on risk management functions and roles.}

Thirdly, it includes contents that enable corporations to identify gaps or differences with their existing codes.

Therefore, the below table D.1 is trying to summarize what are short general corporate governance standards. It is also constructed in the way that being the better understandable criteria.

Table D.1: A summary of A Limited International Corporate Governance standards

\begin{tabular}{|l|l|l|}
\hline Subjects or parties & Main quality factors & Sub quality factors \\
\hline Audit committee & $\begin{array}{l}\text { Vary depends on size, com- } \\
\text { plexity of the firm; }\end{array}$ & $\begin{array}{l}\text { Might be included in the } \\
\text { governance structure; }\end{array}$ \\
\hline CEO and The Chair & Roles can be combined; & $\begin{array}{l}\text { The Chair can be support- } \\
\text { ed by Vice Chairman; }\end{array}$ \\
\hline Corporate Secretary & $\begin{array}{l}\text { N/A (for further research } \\
\text { and implementation) }\end{array}$ & $\begin{array}{l}\text { N/A (for further research } \\
\text { and implementation) }\end{array}$ \\
\hline Compliance officer & $\begin{array}{l}\text { "Comply or explain" mecha- } \\
\text { nism; }\end{array}$ & Sound legal framework; \\
\hline Board of Directors & Independent leadership; & Two tier system; \\
\hline Independent director & $\begin{array}{l}\text { Attend committee and Board } \\
\text { meetings; }\end{array}$ & May from private sector; \\
\hline $\begin{array}{l}\text { Supervisory board to } \\
\text { the Management }\end{array}$ & $\begin{array}{l}\text { Form a governance struc- } \\
\text { ture, together with Board of } \\
\text { Directors and Management; }\end{array}$ & $\begin{array}{l}\text { N/A (for further research } \\
\text { and implementation) }\end{array}$ \\
\hline $\begin{array}{l}\text { Supervisory to the } \\
\text { Board of Directors }\end{array}$ & $\begin{array}{l}\text { Can be independent external } \\
\text { advisers; }\end{array}$ & $\begin{array}{l}\text { Can compose of govern- } \\
\text { ment authorities; }\end{array}$ \\
\hline Internal control & $\begin{array}{l}\text { Identify risk bearing capacity, } \\
\text { risk tolerance level; }\end{array}$ & $\begin{array}{l}\text { Used by The Board to } \\
\text { mitigate risks; }\end{array}$ \\
\hline $\begin{array}{l}\text { Board determines scope and } \\
\text { duties of I.A; }\end{array}$ & $\begin{array}{l}\text { Independence; Integrity; } \\
\text { Competency; }\end{array}$ & $\begin{array}{l}\text { Audit internally activities; } \\
\text { auditors; Avoid interest } \\
\text { conflicts in non-audit } \\
\text { services; }\end{array}$ \\
\hline External audit & $\begin{array}{l}\text { How shareholders exercise } \\
\text { their control rights; }\end{array}$ & $\begin{array}{l}\text { Information equally avail- } \\
\text { able to all shareholders; }\end{array}$ \\
\hline
\end{tabular}




\begin{tabular}{|l|l|l|}
\hline Shareholders & $\begin{array}{l}\text { Participate effectively in } \\
\text { general meetings; }\end{array}$ & $\begin{array}{l}\text { Aware of type, number, } \\
\text { duties of outside manage- } \\
\text { ment positions held by } \\
\text { individual director; }\end{array}$ \\
\hline Employee & $\begin{array}{l}\text { appropriately qualified and } \\
\text { well-trained; }\end{array}$ & $\begin{array}{l}\text { Professional ethical stand- } \\
\text { ards; }\end{array}$ \\
\hline $\begin{array}{l}\text { The corporation as a } \\
\text { whole entity }\end{array}$ & $\begin{array}{l}\text { maximize the long-term } \\
\text { return to shareholders }\end{array}$ & $\begin{array}{l}\text { Can have ethics commit- } \\
\text { tee; Senior ethics officer; }\end{array}$ \\
\hline The Code & $\begin{array}{l}\text { Promote long term sustain- } \\
\text { ability of the enterprise; } \\
\text { clear and effective division of } \\
\text { roles and duties; }\end{array}$ & $\begin{array}{l}\text { Existence of Code of eth- } \\
\text { ics; high level of integrity; }\end{array}$ \\
\hline
\end{tabular}

\section{$<$ D.2>-Group 2 - Relative Russian and North European Corporate}

\section{Governance Standards}

$<a>$ The Norwegian Code of Practice for Corporate Governance 2010

One advantage of the Code is that it pays attention to duties of the nomination committee. For example, it stated the committee should note the Board's report on performance.

Furthermore, it also shows the connection b.t the Code and the Public Company Act (PCA) or Securities Trading Act or Auditing and Auditors Act. For example, the 21-day notice deadline in PCA for general meeting. Also, while the relevant regulation allows 4-year term for Board, the Code suggests max 2 years term.

In the Norwegian Code 2010, it specifies that the Code may a little more restrictive than the Public Company Act in a sense that it allows 1 class, whereas the Act permits different classes of share. This can be considered as another advantage.

However, it would be better if the Code mentions more about qualities of CEO and compliance officer or secretary.

Table D.2: Norwegian Corporate Governance code 2010 (a short summary evaluation)

\begin{tabular}{|l|l|l|l|l|l|}
\hline $\begin{array}{l}\text { Sub- } \\
\text { jects or } \\
\text { parties }\end{array}$ & $\begin{array}{l}\text { Main quality } \\
\text { factors }\end{array}$ & $\begin{array}{l}\text { Sub quality } \\
\text { factors }\end{array}$ & Responsibilities & Objectives & Note \\
\hline
\end{tabular}




\begin{tabular}{|c|c|c|c|c|}
\hline $\begin{array}{l}\text { Audit } \\
\text { com- } \\
\text { mittee }\end{array}$ & $\begin{array}{l}\text { Ensure the } \\
\text { greatest inde- } \\
\text { pendence for } \\
\text { Board; }\end{array}$ & $\begin{array}{l}\text { can be } \\
\text { formed in } \\
\text { smaller firms; }\end{array}$ & $\begin{array}{l}\text { Present at the } \\
\text { general meeting; } \\
\text { receives plan from } \\
\text { auditors annually; }\end{array}$ & $\begin{array}{l}\text { Not } \\
\text { mentioned } \\
\text { clearly in } \\
\text { the Code }\end{array}$ \\
\hline $\begin{array}{l}\text { Nomi- } \\
\text { nation } \\
\text { com- } \\
\text { mittee }\end{array}$ & $\begin{array}{l}\text { Duties guided } \\
\text { by the general } \\
\text { meeting; at } \\
\text { least } 1 \text { mem- } \\
\text { ber not in the } \\
\text { Board; avoid } \\
\text { conflicts of } \\
\text { interest b.t } \\
\text { candidates } \\
\text { and members; }\end{array}$ & $\begin{array}{l}\text { Chair , mem- } \\
\text { bers elected } \\
\text { by GM; inde- } \\
\text { pendence; } \\
\text { composi- } \\
\text { tion reflects } \\
\text { shareholders' } \\
\text { interests }\end{array}$ & $\begin{array}{l}\text { Present at the } \\
\text { general meeting; } \\
\text { present recommen- } \\
\text { dations, answers; } \\
\text { give information of } \\
\text { members on web; } \\
\text { elect candidates } \\
\text { not proposed by } \\
\text { board; use firm's } \\
\text { resources; advice } \\
\text { from outside; }\end{array}$ & $\begin{array}{l}\text { Not } \\
\text { mentioned } \\
\text { clearly in } \\
\text { the Code }\end{array}$ \\
\hline $\begin{array}{l}\text { Com- } \\
\text { pensa- } \\
\text { tion or } \\
\text { Remu- } \\
\text { nera- } \\
\text { tion } \\
\text { com- } \\
\text { mittee }\end{array}$ & $\begin{array}{l}\text { Not men- } \\
\text { tioned clearly } \\
\text { in the Code }\end{array}$ & $\begin{array}{l}\text { Remunera- } \\
\text { tion reflects } \\
\text { boards' } \\
\text { expertise, du- } \\
\text { ties, time; }\end{array}$ & $\begin{array}{l}\text { Set absolute remu- } \\
\text { neration limit for } \\
\text { executive; remu- } \\
\text { neration guidelines } \\
\text { for executive; }\end{array}$ & $\begin{array}{l}\text { Not } \\
\text { mentioned } \\
\text { clearly in } \\
\text { the Code }\end{array}$ \\
\hline CEO & $\begin{array}{l}\text { Not men- } \\
\text { tioned clearly } \\
\text { in the Code }\end{array}$ & $\begin{array}{l}\text { Not in the } \\
\text { nomination } \\
\text { committee; } \\
\text { not be a } \\
\text { Board mem- } \\
\text { ber; }\end{array}$ & $\begin{array}{l}\text { May not make a } \\
\text { decision at the } \\
\text { expense of other } \\
\text { shareholders; }\end{array}$ & $\begin{array}{l}\text { Not } \\
\text { mentioned } \\
\text { clearly in } \\
\text { the Code }\end{array}$ \\
\hline $\begin{array}{l}\text { The } \\
\text { Chair }\end{array}$ & $\begin{array}{l}\text { The Chair of } \\
\text { the board } \\
\text { elected by } \\
\text { corporate as- } \\
\text { sembly; }\end{array}$ & $\begin{array}{l}\text { Independent } \\
\text { chairman for } \\
\text { GM; have } \\
\text { chairman for } \\
\text { nomination } \\
\text { committee; }\end{array}$ & $\begin{array}{l}\text { The chairman of } \\
\text { board elected by } \\
\text { general meeting; } \\
\text { ensure well-organ- } \\
\text { ized Board jobs; } \\
\text { holding training for } \\
\text { Board; }\end{array}$ & $\begin{array}{l}\text { Not } \\
\text { mentioned } \\
\text { clearly in } \\
\text { the Code }\end{array}$ \\
\hline $\begin{array}{l}\text { CEO } \\
\text { and The } \\
\text { Chair } \\
\text { rela- } \\
\text { tionship }\end{array}$ & $\begin{array}{l}\text { Not men- } \\
\text { tioned clearly } \\
\text { in the Code }\end{array}$ & $\begin{array}{l}\text { Tasks may be } \\
\text { delegated by } \\
\text { Board; }\end{array}$ & $\begin{array}{l}\text { Attend general } \\
\text { meeting; }\end{array}$ & $\begin{array}{l}\text { Not } \\
\text { mentioned } \\
\text { clearly in } \\
\text { the Code }\end{array}$ \\
\hline $\begin{array}{l}\text { Cor- } \\
\text { porate } \\
\text { Secre- } \\
\text { tary }\end{array}$ & $\begin{array}{l}\text { Not men- } \\
\text { tioned clearly } \\
\text { in the Code }\end{array}$ & $\begin{array}{l}\text { Not men- } \\
\text { tioned clearly } \\
\text { in the Code }\end{array}$ & $\begin{array}{l}\text { Not mentioned } \\
\text { clearly in the Code }\end{array}$ & $\begin{array}{l}\text { Not } \\
\text { mentioned } \\
\text { clearly in } \\
\text { the Code }\end{array}$ \\
\hline
\end{tabular}




\begin{tabular}{|c|c|c|c|c|c|}
\hline $\begin{array}{l}\text { Compli- } \\
\text { ance } \\
\text { officer }\end{array}$ & $\begin{array}{l}\text { Not men- } \\
\text { tioned clearly } \\
\text { in the Code }\end{array}$ & $\begin{array}{l}\text { Not men- } \\
\text { tioned clearly } \\
\text { in the Code }\end{array}$ & $\begin{array}{l}\text { Not mentioned } \\
\text { clearly in the Code }\end{array}$ & $\begin{array}{l}\text { Not } \\
\text { mentioned } \\
\text { clearly in } \\
\text { the Code }\end{array}$ & \\
\hline $\begin{array}{l}\text { Board } \\
\text { of Di- } \\
\text { rectors }\end{array}$ & $\begin{array}{l}\text { Valued by an } \\
\text { independent } \\
\text { expert (in } \\
\text { take-overs); } \\
\text { have sufficient } \\
\text { time as direc- } \\
\text { tor; male/fe- } \\
\text { male balance; } \\
\text { background } \\
\text { diversity; }\end{array}$ & $\begin{array}{l}\text { Prevention of } \\
\text { corruption; } \\
\text { Present at } \\
\text { the general } \\
\text { meeting; not } \\
\text { in the nomi- } \\
\text { nation com- } \\
\text { mittee; term } \\
\text { max } 2 \text { years; } \\
\text { teamwork; }\end{array}$ & $\begin{array}{l}\text { Define corporate } \\
\text { values, ethical } \\
\text { guidelines; include } \\
\text { CG in annual } \\
\text { report; Consider } \\
\text { each section of } \\
\text { the code; how } \\
\text { the firm meet the } \\
\text { requirements; Set } \\
\text { clear, predictable } \\
\text { dividend policy; can } \\
\text { own shares; lead } \\
\text { strategic planning; } \\
\text { value individuals } \\
\text { and groups; } \\
\end{array}$ & $\begin{array}{l}\text { Sound } \\
\text { corporate } \\
\text { govern- } \\
\text { ance; }\end{array}$ & $\begin{array}{l}\text { under- } \\
\text { stood } \\
\text { from the } \\
\text { Code; }\end{array}$ \\
\hline $\begin{array}{l}\text { Ex- } \\
\text { ecutive } \\
\text { director }\end{array}$ & $\begin{array}{l}\text { absolute } \\
\text { remuneration } \\
\text { limit for execu- } \\
\text { tive; }\end{array}$ & $\begin{array}{l}\text { Remunera- } \\
\text { tion involves } \\
\text { share, bonus, } \\
\text { and has abso- } \\
\text { lute limit; }\end{array}$ & $\begin{array}{l}\text { Notify if they have } \\
\text { direct/indirect } \\
\text { interest in related } \\
\text { transaction with } \\
\text { the co.; can hold a } \\
\text { big proportion of } \\
\text { share; }\end{array}$ & $\begin{array}{l}\text { Not } \\
\text { mentioned } \\
\text { clearly in } \\
\text { the Code }\end{array}$ & \\
\hline $\begin{array}{l}\text { Non-ex- } \\
\text { ecutive } \\
\text { director }\end{array}$ & $\begin{array}{l}\text { Not men- } \\
\text { tioned clearly } \\
\text { in the Code }\end{array}$ & $\begin{array}{l}\text { Not men- } \\
\text { tioned clearly } \\
\text { in the Code }\end{array}$ & $\begin{array}{l}\text { Not mentioned } \\
\text { clearly in the Code }\end{array}$ & $\begin{array}{l}\text { Not } \\
\text { mentioned } \\
\text { clearly in } \\
\text { the Code }\end{array}$ & \\
\hline $\begin{array}{l}\text { Inde- } \\
\text { pend- } \\
\text { ent } \\
\text { director } \\
\end{array}$ & $\begin{array}{l}\text { Not men- } \\
\text { tioned clearly } \\
\text { in the Code }\end{array}$ & $\begin{array}{l}\text { Not men- } \\
\text { tioned clearly } \\
\text { in the Code }\end{array}$ & $\begin{array}{l}\text { Not mentioned } \\
\text { clearly in the Code }\end{array}$ & $\begin{array}{l}\text { Not } \\
\text { mentioned } \\
\text { clearly in } \\
\text { the Code } \\
\end{array}$ & \\
\hline CFO & $\begin{array}{l}\text { Not men- } \\
\text { tioned clearly } \\
\text { in the Code }\end{array}$ & $\begin{array}{l}\text { Not men- } \\
\text { tioned clearly } \\
\text { in the Code }\end{array}$ & $\begin{array}{l}\text { Not mentioned } \\
\text { clearly in the Code }\end{array}$ & $\begin{array}{l}\text { Not } \\
\text { mentioned } \\
\text { clearly in } \\
\text { the Code }\end{array}$ & \\
\hline $\begin{array}{l}\text { Man- } \\
\text { age- } \\
\text { ment } \\
\text { team }\end{array}$ & $\begin{array}{l}\text { Not men- } \\
\text { tioned clearly } \\
\text { in the Code }\end{array}$ & $\begin{array}{l}\text { Not men- } \\
\text { tioned clearly } \\
\text { in the Code }\end{array}$ & $\begin{array}{l}\text { Have independence } \\
\text { responsibility in bid } \\
\text { situation; }\end{array}$ & $\begin{array}{l}\text { Not } \\
\text { mentioned } \\
\text { clearly in } \\
\text { the Code }\end{array}$ & \\
\hline
\end{tabular}




\begin{tabular}{|c|c|c|c|c|c|}
\hline $\begin{array}{l}\text { Super- } \\
\text { visory } \\
\text { board }\end{array}$ & $\begin{array}{l}\text { Not men- } \\
\text { tioned clearly } \\
\text { in the Code }\end{array}$ & $\begin{array}{l}\text { Use inde- } \\
\text { pendent } \\
\text { expert in } \\
\text { take-overs } \\
\text { valuation and } \\
\text { explanation } \\
\text { to public; } \\
\end{array}$ & $\begin{array}{l}\text { The corporate } \\
\text { assembly super- } \\
\text { vises the board and } \\
\text { executive manage- } \\
\text { ment; }\end{array}$ & $\begin{array}{l}\text { Not } \\
\text { mentioned } \\
\text { clearly in } \\
\text { the Code }\end{array}$ & \\
\hline $\begin{array}{l}\text { Internal } \\
\text { control }\end{array}$ & $\begin{array}{l}\text { Effective } \\
\text { operational ar- } \\
\text { rangements; }\end{array}$ & $\begin{array}{l}\text { Relating } \\
\text { to Board } \\
\text { supervision; } \\
\text { in accordance } \\
\text { with legisla- } \\
\text { tion; }\end{array}$ & $\begin{array}{l}\text { Involves guidelines } \\
\text { for CSR; annually } \\
\text { reviewed by board } \\
\text { and on shortcom- } \\
\text { ings; reviewed by } \\
\text { auditors with pro- } \\
\text { posals for improve- } \\
\text { ment; }\end{array}$ & $\begin{array}{l}\text { Sound } \\
\text { internal } \\
\text { control and } \\
\text { RM system; }\end{array}$ & \\
\hline $\begin{array}{l}\text { Internal } \\
\text { audit }\end{array}$ & $\begin{array}{l}\text { Not men- } \\
\text { tioned clearly } \\
\text { in the Code }\end{array}$ & $\begin{array}{l}\text { annually } \\
\text { reviewed by } \\
\text { board; }\end{array}$ & $\begin{array}{l}\text { Board receives } \\
\text { routine report; }\end{array}$ & $\begin{array}{l}\text { Not } \\
\text { mentioned } \\
\text { clearly in } \\
\text { the Code }\end{array}$ & \\
\hline $\begin{array}{l}\text { External } \\
\text { audit }\end{array}$ & $\begin{array}{l}\text { Not men- } \\
\text { tioned clearly } \\
\text { in the Code }\end{array}$ & $\begin{array}{l}\text { Knowledge, } \\
\text { experience; }\end{array}$ & $\begin{array}{l}\text { Present at the } \\
\text { general meeting; } \\
\text { once a year review } \\
\text { internal control } \\
\text { procedures; }\end{array}$ & $\begin{array}{l}\text { Not } \\
\text { mentioned } \\
\text { clearly in } \\
\text { the Code }\end{array}$ & $\begin{array}{l}\text { From } \\
\text { the } \\
\text { code; }\end{array}$ \\
\hline $\begin{array}{l}\text { Disclo- } \\
\text { sure } \\
\text { and } \\
\text { trans- } \\
\text { parency }\end{array}$ & $\begin{array}{l}\text { Information } \\
\text { published to } \\
\text { provide pre- } \\
\text { dictability to } \\
\text { shareholders; }\end{array}$ & $\begin{array}{l}\text { Firm informa- } \\
\text { tion in both } \\
\text { Norwegian } \\
\text { and English } \\
\text { considering } \\
\text { shareholders; }\end{array}$ & $\begin{array}{l}\text { Report CG in annual } \\
\text { report; disclose } \\
\text { dividend policy; } \\
\text { Give information to } \\
\text { nominate a candi- } \\
\text { date for a board on } \\
\text { web; }\end{array}$ & $\begin{array}{l}\text { Not } \\
\text { mentioned } \\
\text { clearly in } \\
\text { the Code }\end{array}$ & \\
\hline $\begin{array}{l}\text { Share- } \\
\text { holders } \\
\text { and Mi- } \\
\text { nority } \\
\text { Stock- } \\
\text { holder }\end{array}$ & $\begin{array}{l}\text { Equal treat- } \\
\text { ment; the firm } \\
\text { only has } 1 \\
\text { class of share; } \\
21 \text { day notice } \\
\text { prior the GM; }\end{array}$ & $\begin{array}{l}\text { The firm } \\
\text { explains the } \\
\text { justification } \\
\text { from waiving } \\
\text { the pre-emp- } \\
\text { tion rights; at } \\
\text { least } 2 \text { Board } \\
\text { members } \\
\text { independ- } \\
\text { ent of main } \\
\text { shareholders; }\end{array}$ & $\begin{array}{l}\text { Can value whether } \\
\text { the firm follows } \\
\text { good CG; can } \\
\text { anticipate the firm } \\
\text { scopes; exercise } \\
\text { rights as many } \\
\text { as possible; use } \\
\text { electronic means } \\
\text { in GM; }\end{array}$ & $\begin{array}{l}\text { Not } \\
\text { mentioned } \\
\text { clearly in } \\
\text { the Code }\end{array}$ & $\begin{array}{l}\text { Under- } \\
\text { stood } \\
\text { from the } \\
\text { code } \\
\text { and } \\
\text { public } \\
\text { co. act; }\end{array}$ \\
\hline
\end{tabular}




\begin{tabular}{|c|c|c|c|c|c|}
\hline $\begin{array}{l}\text { Finan- } \\
\text { cial re- } \\
\text { porting } \\
\text { stand- } \\
\text { ards }\end{array}$ & $\begin{array}{l}\text { In accordance } \\
\text { with gener- } \\
\text { ally accepted } \\
\text { accounting } \\
\text { standards and } \\
\text { actual situa- } \\
\text { tion; }\end{array}$ & $\begin{array}{l}\text { Not men- } \\
\text { tioned clearly } \\
\text { in the Code }\end{array}$ & $\begin{array}{l}\text { Not mentioned } \\
\text { clearly in the Code }\end{array}$ & $\begin{array}{l}\text { Not } \\
\text { mentioned } \\
\text { clearly in } \\
\text { the Code }\end{array}$ & \\
\hline $\begin{array}{l}\text { Em- } \\
\text { ployee }\end{array}$ & $\begin{array}{l}\text { Their rights } \\
\text { included in } \\
\text { CSR; }\end{array}$ & $\begin{array}{l}\text { Not men- } \\
\text { tioned clearly } \\
\text { in the Code }\end{array}$ & $\begin{array}{l}\text { Follow ethical } \\
\text { guidelines to } \\
\text { communicate with } \\
\text { Board; }\end{array}$ & $\begin{array}{l}\text { Not } \\
\text { mentioned } \\
\text { clearly in } \\
\text { the Code }\end{array}$ & \\
\hline Note & \multicolumn{5}{|c|}{$\begin{array}{l}\text { The underlined part is describing some more works needed to be done for } \\
\text { relevant subjects and parties. }\end{array}$} \\
\hline
\end{tabular}

\section{$<b>$ Finish Code of Corporate Governance 2010}

One of its distinctions is mentioning information on board and committees and supervisory board that a firm needs to disclose in 5 years.

Besides, the Code addressed its view of taking 2 statements: CG and remuneration statements of the company. It emphasizes the web disclosure on these. But, it still needs more information on corporate secretary or compliance officer.

Table D.3: Finish Corporate Governance code 2010 (a short summary evaluation)

\begin{tabular}{|l|l|l|l|l|l|}
\hline $\begin{array}{l}\text { Subjects } \\
\text { or parties }\end{array}$ & $\begin{array}{l}\text { Main quality } \\
\text { factors }\end{array}$ & $\begin{array}{l}\text { Sub qual- } \\
\text { ity factors }\end{array}$ & Responsibilities & Objectives & Note \\
\hline $\begin{array}{l}\text { Audit } \\
\text { commit- } \\
\text { tee }\end{array}$ & $\begin{array}{l}\text { At least 1 mem- } \\
\text { ber have exper- } \\
\text { tise in auditing } \\
\text { or accounting; at } \\
\text { least 1 independ- } \\
\text { ent of significant } \\
\text { shareholders; }\end{array}$ & $\begin{array}{l}\text { Expertise } \\
\text { in internal } \\
\text { audit, } \\
\text { book- } \\
\text { keeping, } \\
\text { manage- } \\
\text { ment; }\end{array}$ & $\begin{array}{l}\text { Relevant to financial } \\
\text { reporting and control; } \\
\text { supervise financial } \\
\text { reporting; evalu- } \\
\text { ate compliance with } \\
\text { laws; }\end{array}$ & $\begin{array}{l}\text { Not men- } \\
\text { tioned } \\
\text { clearly in } \\
\text { the Code }\end{array}$ & \\
\hline $\begin{array}{l}\text { Nomina- } \\
\text { tion com- } \\
\text { mittee }\end{array}$ & $\begin{array}{l}\text { Independent; } \\
\text { directors; }\end{array}$ & $\begin{array}{l}\text { Consists of } \\
\text { directors at GM; }\end{array}$ & $\begin{array}{l}\text { Not men- } \\
\text { tioned } \\
\text { clearly in } \\
\text { the Code }\end{array}$ & \\
\hline
\end{tabular}




\begin{tabular}{|c|c|c|c|c|}
\hline $\begin{array}{l}\text { Compen- } \\
\text { sation or } \\
\text { Remu- } \\
\text { neration } \\
\text { commit- } \\
\text { tee } \\
\end{array}$ & $\begin{array}{l}\text { Not mentioned } \\
\text { clearly in the } \\
\text { Code }\end{array}$ & $\begin{array}{l}\text { Majority } \\
\text { be inde- } \\
\text { pendent; } \\
\text { can use } \\
\text { external } \\
\text { adviser; }\end{array}$ & $\begin{array}{l}\text { Appoint managing } \\
\text { director; remunera- } \\
\text { tion schemes; }\end{array}$ & $\begin{array}{l}\text { Not men- } \\
\text { tioned } \\
\text { clearly in } \\
\text { the Code }\end{array}$ \\
\hline $\begin{array}{l}\text { CEO or } \\
\text { managing } \\
\text { director }\end{array}$ & $\begin{array}{l}\text { Appointed/ } \\
\text { authorized by } \\
\text { board; }\end{array}$ & $\begin{array}{l}\text { Not the } \\
\text { chairman } \\
\text { of the } \\
\text { board; }\end{array}$ & $\begin{array}{l}\text { Day to day manage- } \\
\text { ment; }\end{array}$ & $\begin{array}{l}\text { Ensure ac- } \\
\text { counting } \\
\text { practice } \\
\text { comply } \\
\text { with laws; }\end{array}$ \\
\hline The Chair & $\begin{array}{l}\text { Not mentioned } \\
\text { clearly in the } \\
\text { Code }\end{array}$ & $\begin{array}{l}\text { Perform a } \\
\text { consid- } \\
\text { erable } \\
\text { amount of } \\
\text { job; }\end{array}$ & Attends GM; & $\begin{array}{l}\text { Not men- } \\
\text { tioned } \\
\text { clearly in } \\
\text { the Code }\end{array}$ \\
\hline $\begin{array}{l}\text { CEO and } \\
\text { The Chair } \\
\text { relation- } \\
\text { ship }\end{array}$ & $\begin{array}{l}\text { Not mentioned } \\
\text { clearly in the } \\
\text { Code }\end{array}$ & $\begin{array}{l}\text { Not men- } \\
\text { tioned } \\
\text { clearly in } \\
\text { the Code }\end{array}$ & $\begin{array}{l}\text { Subject to develop- } \\
\text { ment phases, roles } \\
\text { can be combined }\end{array}$ & $\begin{array}{l}\text { Not men- } \\
\text { tioned } \\
\text { clearly in } \\
\text { the Code }\end{array}$ \\
\hline $\begin{array}{l}\text { Corporate } \\
\text { Secretary }\end{array}$ & $\begin{array}{l}\text { Not mentioned } \\
\text { clearly in the } \\
\text { Code }\end{array}$ & $\begin{array}{l}\text { Not men- } \\
\text { tioned } \\
\text { clearly in } \\
\text { the Code }\end{array}$ & $\begin{array}{l}\text { Not mentioned } \\
\text { clearly in the Code }\end{array}$ & $\begin{array}{l}\text { Not men- } \\
\text { tioned } \\
\text { clearly in } \\
\text { the Code }\end{array}$ \\
\hline $\begin{array}{l}\text { Compli- } \\
\text { ance } \\
\text { officer }\end{array}$ & $\begin{array}{l}\text { Not mentioned } \\
\text { clearly in the } \\
\text { Code }\end{array}$ & $\begin{array}{l}\text { Not men- } \\
\text { tioned } \\
\text { clearly in } \\
\text { the Code }\end{array}$ & $\begin{array}{l}\text { Not mentioned } \\
\text { clearly in the Code }\end{array}$ & $\begin{array}{l}\text { Not men- } \\
\text { tioned } \\
\text { clearly in } \\
\text { the Code }\end{array}$ \\
\hline $\begin{array}{l}\text { Board of } \\
\text { Directors }\end{array}$ & $\begin{array}{l}\text { Expertise, experi- } \\
\text { ence; Perform } \\
\text { a considerable } \\
\text { amount of job; } \\
\text { both genders; at } \\
\text { least } 2 \text { directors } \\
\text { independent of } \\
\text { significant share- } \\
\text { holders }\end{array}$ & $\begin{array}{l}\text { Interac- } \\
\text { tion with } \\
\text { sharehold- } \\
\text { ers in GM; } \\
\text { elected } \\
\text { in GM; } 1 \\
\text { year term; } \\
\text { receive } \\
\text { sufficient } \\
\text { informa- } \\
\text { tion; } \\
\end{array}$ & $\begin{array}{l}\text { First time director } \\
\text { and a sufficient board } \\
\text { members attends } \\
\text { GM; administration } \\
\text { and proper organiza- } \\
\text { tion; }\end{array}$ & $\begin{array}{l}\text { Not men- } \\
\text { tioned } \\
\text { clearly in } \\
\text { the Code }\end{array}$ \\
\hline $\begin{array}{l}\text { Executive } \\
\text { director }\end{array}$ & $\begin{array}{l}\text { Not mentioned } \\
\text { clearly in the } \\
\text { Code }\end{array}$ & $\begin{array}{l}\text { May not in } \\
\text { the nomi- } \\
\text { nation } \\
\text { commit- } \\
\text { tee; }\end{array}$ & $\begin{array}{l}\text { Operative manage- } \\
\text { ment; remuneration } \\
\text { disclosed; }\end{array}$ & $\begin{array}{l}\text { Not men- } \\
\text { tioned } \\
\text { clearly in } \\
\text { the Code }\end{array}$ \\
\hline
\end{tabular}




\begin{tabular}{|c|c|c|c|c|c|}
\hline $\begin{array}{l}\text { Non- } \\
\text { executive } \\
\text { director }\end{array}$ & $\begin{array}{l}\text { Not mentioned } \\
\text { clearly in the } \\
\text { Code }\end{array}$ & $\begin{array}{l}\text { Not men- } \\
\text { tioned } \\
\text { clearly in } \\
\text { the Code }\end{array}$ & $\begin{array}{l}\text { Not mentioned } \\
\text { clearly in the Code }\end{array}$ & $\begin{array}{l}\text { Not men- } \\
\text { tioned } \\
\text { clearly in } \\
\text { the Code }\end{array}$ & \\
\hline $\begin{array}{l}\text { Inde- } \\
\text { pendent } \\
\text { director }\end{array}$ & $\begin{array}{l}\text { Not mentioned } \\
\text { clearly in the } \\
\text { Code }\end{array}$ & $\begin{array}{l}\text { Hold the } \\
\text { majority } \\
\text { of board; }\end{array}$ & $\begin{array}{l}\text { Not mentioned } \\
\text { clearly in the Code }\end{array}$ & $\begin{array}{l}\text { Not men- } \\
\text { tioned } \\
\text { clearly in } \\
\text { the Code }\end{array}$ & \\
\hline CFO & $\begin{array}{l}\text { Not mentioned } \\
\text { clearly in the } \\
\text { Code }\end{array}$ & $\begin{array}{l}\text { Not men- } \\
\text { tioned } \\
\text { clearly in } \\
\text { the Code }\end{array}$ & $\begin{array}{l}\text { Not mentioned } \\
\text { clearly in the Code }\end{array}$ & $\begin{array}{l}\text { Not men- } \\
\text { tioned } \\
\text { clearly in } \\
\text { the Code }\end{array}$ & \\
\hline $\begin{array}{l}\text { Manage- } \\
\text { ment } \\
\text { team }\end{array}$ & $\begin{array}{l}\text { Not mentioned } \\
\text { clearly in the } \\
\text { Code }\end{array}$ & $\begin{array}{l}\text { Not men- } \\
\text { tioned } \\
\text { clearly in } \\
\text { the Code }\end{array}$ & $\begin{array}{l}\text { Not mentioned } \\
\text { clearly in the Code }\end{array}$ & $\begin{array}{l}\text { Not men- } \\
\text { tioned } \\
\text { clearly in } \\
\text { the Code }\end{array}$ & \\
\hline $\begin{array}{l}\text { Super- } \\
\text { visory } \\
\text { board }\end{array}$ & $\begin{array}{l}\text { Not mentioned } \\
\text { clearly in the } \\
\text { Code }\end{array}$ & $\begin{array}{l}\text { Not men- } \\
\text { tioned } \\
\text { clearly in } \\
\text { the Code }\end{array}$ & $\begin{array}{l}\text { Remuneration, com- } \\
\text { position and opera- } \\
\text { tion disclosed; }\end{array}$ & $\begin{array}{l}\text { Not men- } \\
\text { tioned } \\
\text { clearly in } \\
\text { the Code }\end{array}$ & \\
\hline $\begin{array}{l}\text { Internal } \\
\text { control }\end{array}$ & $\begin{array}{l}\text { Not mentioned } \\
\text { clearly in the } \\
\text { Japan Code }\end{array}$ & $\begin{array}{l}\text { risk MGT } \\
\text { a part of } \\
\text { control } \\
\text { system; }\end{array}$ & $\begin{array}{l}\text { Monitored by audit } \\
\text { committee; main } \\
\text { features reviewed } \\
\text { by Audit Committee; } \\
\text { Define principles of } \\
\text { internal control and } \\
\text { risk MGT; risk valued } \\
\text { by board; }\end{array}$ & $\begin{array}{l}\text { Ensure } \\
\text { profitable } \\
\text { opera- } \\
\text { tions of } \\
\text { the firm; }\end{array}$ & \\
\hline $\begin{array}{l}\text { Internal } \\
\text { audit (IA) }\end{array}$ & $\begin{array}{l}\text { Not mentioned } \\
\text { clearly in the } \\
\text { Code }\end{array}$ & $\begin{array}{l}\text { Organiza- } \\
\text { tion of IA } \\
\text { functions } \\
\text { disclosed; }\end{array}$ & $\begin{array}{l}\text { Monitored by audit } \\
\text { committee; instruc- } \\
\text { tions approved by } \\
\text { audit committee; }\end{array}$ & $\begin{array}{l}\text { Not men- } \\
\text { tioned } \\
\text { clearly in } \\
\text { the Code }\end{array}$ & \\
\hline $\begin{array}{l}\text { External } \\
\text { audit }\end{array}$ & $\begin{array}{l}\text { Not mentioned } \\
\text { clearly in the } \\
\text { Code }\end{array}$ & $\begin{array}{l}\text { term not } \\
\text { > } 7 \text { years; } \\
\text { audit and } \\
\text { non-audit } \\
\text { service } \\
\text { fees dis- } \\
\text { closed; }\end{array}$ & $\begin{array}{l}\text { Present at GM; } \\
\text { gives shareholders } \\
\text { independent opinion } \\
\text { on F.S; }\end{array}$ & $\begin{array}{l}\text { Not men- } \\
\text { tioned } \\
\text { clearly in } \\
\text { the Code }\end{array}$ & $\begin{array}{l}\text { From } \\
\text { the } \\
\text { code; }\end{array}$ \\
\hline
\end{tabular}




\begin{tabular}{|c|c|c|c|c|c|}
\hline $\begin{array}{l}\text { Disclo- } \\
\text { sure and } \\
\text { transpar- } \\
\text { ency }\end{array}$ & $\begin{array}{l}\text { Reliable, up to } \\
\text { date information } \\
\text { distribution; }\end{array}$ & $\begin{array}{l}\text { Insider } \\
\text { admin- } \\
\text { istration } \\
\text { systemati- } \\
\text { cally and } \\
\text { reliably or- } \\
\text { ganized; }\end{array}$ & $\begin{array}{l}\text { GM minutes present- } \\
\text { ed on web; disclose } \\
\text { contract benefits of } \\
\text { managing director; } \\
\text { disclose major risks } \\
\text { and uncertainties; }\end{array}$ & $\begin{array}{l}\text { Not men- } \\
\text { tioned } \\
\text { clearly in } \\
\text { the Code }\end{array}$ & \\
\hline $\begin{array}{l}\text { Share- } \\
\text { holders } \\
\text { and } \\
\text { Minor- } \\
\text { ity Stock- } \\
\text { holder }\end{array}$ & $\begin{array}{l}\text { Not mentioned } \\
\text { clearly in the } \\
\text { Code }\end{array}$ & $\begin{array}{l}\text { Equal } \\
\text { treat- } \\
\text { ment; GM } \\
\text { held after } \\
6 \text { month } \\
\text { of fiscal } \\
\text { year; }\end{array}$ & $\begin{array}{l}\text { Extra GM organized if } \\
\text { at least shareholders } \\
\text { with } 10 \% \text { shares de- } \\
\text { mand; ask questions } \\
\text { in GM; elect board } \\
\text { and auditors; }\end{array}$ & $\begin{array}{l}\text { Not men- } \\
\text { tioned } \\
\text { clearly in } \\
\text { the Code }\end{array}$ & \\
\hline $\begin{array}{l}\text { Financial } \\
\text { reporting } \\
\text { standards }\end{array}$ & $\begin{array}{l}\text { Not mentioned } \\
\text { clearly in the } \\
\text { Code }\end{array}$ & $\begin{array}{l}\text { Done by } \\
\text { auditor; }\end{array}$ & $\begin{array}{l}\text { Not mentioned } \\
\text { clearly in the Code }\end{array}$ & $\begin{array}{l}\text { Not men- } \\
\text { tioned } \\
\text { clearly in } \\
\text { the Code }\end{array}$ & \\
\hline Employee & $\begin{array}{l}\text { Not mentioned } \\
\text { clearly in the } \\
\text { Code }\end{array}$ & $\begin{array}{l}\text { Not men- } \\
\text { tioned } \\
\text { clearly in } \\
\text { the Code }\end{array}$ & $\begin{array}{l}\text { Not mentioned } \\
\text { clearly in the Code }\end{array}$ & $\begin{array}{l}\text { Not men- } \\
\text { tioned } \\
\text { clearly in } \\
\text { the Code }\end{array}$ & \\
\hline Note & \multicolumn{5}{|c|}{$\begin{array}{l}\text { The underlined part is describing some more works needed to be done for } \\
\text { relevant subjects and parties. }\end{array}$} \\
\hline
\end{tabular}

\section{$<c>$ Russian Corporate Governance Code 2002}

One of its distinctions is mentioning the issuing of the Code for joint stock companies will help them to access capital markets..

Besides, the Russian Code has an advantage when it suggests the company should have a strategic planning committee and the committee for conflicts settlement. Furthermore, it pays attention to roles of corporate secretary.

And it has advantages in mentioning ethical standards regarding to products, environment and safety. However it needs modifications on compliance officer and supervisory board roles.

Table D.4: Russian Corporate Governance code 2002 (a short summary evaluation)

\begin{tabular}{|l|l|l|l|l|l|}
\hline $\begin{array}{l}\text { Subjects } \\
\text { or parties }\end{array}$ & $\begin{array}{l}\text { Main quality } \\
\text { factors }\end{array}$ & $\begin{array}{l}\text { Sub quality } \\
\text { factors }\end{array}$ & Responsibilities & $\begin{array}{l}\text { Objec- } \\
\text { tives }\end{array}$ & Note \\
\hline
\end{tabular}




\begin{tabular}{|c|c|c|c|c|}
\hline $\begin{array}{l}\text { Audit } \\
\text { commit- } \\
\text { tee }\end{array}$ & $\begin{array}{l}\text { Unlimited } \\
\text { access to } \\
\text { firm informa- } \\
\text { tion; }\end{array}$ & $\begin{array}{l}\text { Meeting at } \\
\text { least once } \\
\text { a month; }\end{array}$ & $\begin{array}{l}\text { Control financial and } \\
\text { business operations; } \\
\text { evaluate nominee auditor; } \\
\text { questioned by sharehold- } \\
\text { ers; suggest independent } \\
\text { auditor; opinions on errors } \\
\text { of business and risks; }\end{array}$ & $\begin{array}{l}\text { Ensure } \\
\text { proper } \\
\text { supervi- } \\
\text { sion of } \\
\text { firm's } \\
\text { financial } \\
\text { activities }\end{array}$ \\
\hline $\begin{array}{l}\text { Nomina- } \\
\text { tion com- } \\
\text { mittee }\end{array}$ & $\begin{array}{l}\text { Not men- } \\
\text { tioned } \\
\text { clearly in the } \\
\text { Code }\end{array}$ & $\begin{array}{l}\text { Not } \\
\text { mentioned } \\
\text { clearly in } \\
\text { the Code }\end{array}$ & $\begin{array}{l}\text { Not mentioned clearly in } \\
\text { the Code }\end{array}$ & $\begin{array}{l}\text { Not men- } \\
\text { tioned } \\
\text { clearly in } \\
\text { the Code }\end{array}$ \\
\hline $\begin{array}{l}\text { Compen- } \\
\text { sation or } \\
\text { Remu- } \\
\text { neration } \\
\text { commit- } \\
\text { tee }\end{array}$ & $\begin{array}{l}\text { Not men- } \\
\text { tioned } \\
\text { clearly in the } \\
\text { Code }\end{array}$ & $\begin{array}{l}\text { Not } \\
\text { mentioned } \\
\text { clearly in } \\
\text { the Code }\end{array}$ & $\begin{array}{l}\text { Attract skilled experts; } \\
\text { evaluate performance of } \\
\text { BD and managerial board; }\end{array}$ & $\begin{array}{l}\text { Not men- } \\
\text { tioned } \\
\text { clearly in } \\
\text { the Code }\end{array}$ \\
\hline $\begin{array}{l}\text { CEO (or } \\
\text { GD) }\end{array}$ & $\begin{array}{l}\text { Elected } \\
\text { through a } \\
\text { transparent } \\
\text { procedures; } \\
\text { Have suf- } \\
\text { ficient time; } \\
\text { professional } \\
\text { qualifica- } \\
\text { tions; }\end{array}$ & $\begin{array}{l}\text { terms and } \\
\text { contract } \\
\text { conditions } \\
\text { approved } \\
\text { by board; } \\
\text { account- } \\
\text { ability; }\end{array}$ & $\begin{array}{l}\text { Present at shareholder } \\
\text { meeting; resolve all corpo- } \\
\text { rate conflict matters not } \\
\text { within authorities of BD; }\end{array}$ & $\begin{array}{l}\text { Not men- } \\
\text { tioned } \\
\text { clearly in } \\
\text { the Code }\end{array}$ \\
\hline The Chair & $\begin{array}{l}\text { Not men- } \\
\text { tioned } \\
\text { clearly in the } \\
\text { Code }\end{array}$ & $\begin{array}{l}\text { Profes- } \\
\text { sional } \\
\text { reputation; } \\
\text { efficient } \\
\text { interaction } \\
\text { b.t board } \\
\text { and other } \\
\text { bodies in } \\
\text { firm; }\end{array}$ & $\begin{array}{l}\text { Chairman of GM answers } \\
\text { directly; form board meet- } \\
\text { ing agenda; organize work } \\
\text { of committee; nominating } \\
\text { boar members for com- } \\
\text { mittee; }\end{array}$ & $\begin{array}{l}\text { Ensure BD } \\
\text { attains its } \\
\text { objec- } \\
\text { tives; }\end{array}$ \\
\hline $\begin{array}{l}\text { CEO and } \\
\text { The Chair } \\
\text { relation- } \\
\text { ship }\end{array}$ & $\begin{array}{l}\text { Not men- } \\
\text { tioned } \\
\text { clearly in the } \\
\text { Code }\end{array}$ & $\begin{array}{l}\text { Not } \\
\text { mentioned } \\
\text { clearly in } \\
\text { the Code }\end{array}$ & $\begin{array}{l}\text { Not mentioned clearly in } \\
\text { the Code }\end{array}$ & $\begin{array}{l}\text { Not men- } \\
\text { tioned } \\
\text { clearly in } \\
\text { the Code }\end{array}$ \\
\hline
\end{tabular}




\begin{tabular}{|c|c|c|c|c|}
\hline $\begin{array}{l}\text { Cor- } \\
\text { porate } \\
\text { Secretary }\end{array}$ & $\begin{array}{l}\text { Not men- } \\
\text { tioned } \\
\text { clearly in the } \\
\text { Code }\end{array}$ & $\begin{array}{l}\text { Knowledge } \\
\text { for proper } \\
\text { perfor- } \\
\text { mance and } \\
\text { functions; } \\
\text { not be } \\
\text { affiliated } \\
\text { person of } \\
\text { firm and } \\
\text { officers; }\end{array}$ & $\begin{array}{l}\text { Ensure shareholder's ac- } \\
\text { cess to company informa- } \\
\text { tion; receive notice from } \\
\text { CEO, managerial board } \\
\text { if any conflicts of com- } \\
\text { pany interests; record the } \\
\text { corporate conflicts; verify } \\
\text { shareholders' information } \\
\text { of owning shares; prepare } \\
\text { for GM; assist board; }\end{array}$ & $\begin{array}{l}\text { Not men- } \\
\text { tioned } \\
\text { clearly in } \\
\text { the Code }\end{array}$ \\
\hline $\begin{array}{l}\text { Compli- } \\
\text { ance } \\
\text { officer }\end{array}$ & $\begin{array}{l}\text { Not men- } \\
\text { tioned } \\
\text { clearly in the } \\
\text { Code }\end{array}$ & $\begin{array}{l}\text { Not } \\
\text { mentioned } \\
\text { clearly in } \\
\text { the Code }\end{array}$ & $\begin{array}{l}\text { Not mentioned clearly in } \\
\text { the Code }\end{array}$ & $\begin{array}{l}\text { Not men- } \\
\text { tioned } \\
\text { clearly in } \\
\text { the Code }\end{array}$ \\
\hline $\begin{array}{l}\text { Board of } \\
\text { Directors }\end{array}$ & $\begin{array}{l}\text { Accountabil- } \\
\text { ity; authority } \\
\text { defined in } \\
\text { company } \\
\text { charter; } \\
\text { reputation; } \\
\text { all access to } \\
\text { necessary } \\
\text { information; }\end{array}$ & $\begin{array}{l}\text { Elected } \\
\text { through a } \\
\text { transparent } \\
\text { proce- } \\
\text { dures; } \\
\text { knowl- } \\
\text { edge, skill, } \\
\text { experience; } \\
\text { meeting } \\
\text { minutes } \\
\text { kept; have } \\
\text { liability } \\
\text { insurance; }\end{array}$ & $\begin{array}{l}\text { Strategic management, } \\
\text { effective control, account- } \\
\text { ability; Present at share- } \\
\text { holder meeting; good } \\
\text { faith; not disclose insider } \\
\text { information; }\end{array}$ & $\begin{array}{l}\text { The most } \\
\text { efficient } \\
\text { functions } \\
\text { perfor- } \\
\text { mance; }\end{array}$ \\
\hline $\begin{array}{l}\text { Executive } \\
\text { director }\end{array}$ & $\begin{array}{l}\text { Not > } 1 / 4 \\
\text { board mem- } \\
\text { bers; }\end{array}$ & $\begin{array}{l}\text { Elected } \\
\text { through a } \\
\text { transparent } \\
\text { proce- } \\
\text { dures; }\end{array}$ & $\begin{array}{l}\text { Member of board of direc- } \\
\text { tor and managerial board; }\end{array}$ & $\begin{array}{l}\text { Not men- } \\
\text { tioned } \\
\text { clearly in } \\
\text { the Code }\end{array}$ \\
\hline $\begin{array}{l}\text { Non- } \\
\text { executive } \\
\text { director }\end{array}$ & $\begin{array}{l}\text { Not men- } \\
\text { tioned } \\
\text { clearly in the } \\
\text { Code }\end{array}$ & $\begin{array}{l}\text { Included in } \\
\text { board; }\end{array}$ & $\begin{array}{l}\text { Not mentioned clearly in } \\
\text { the Code }\end{array}$ & $\begin{array}{l}\text { Not men- } \\
\text { tioned } \\
\text { clearly in } \\
\text { the Code }\end{array}$ \\
\hline $\begin{array}{l}\text { Inde- } \\
\text { pendent } \\
\text { director }\end{array}$ & $\begin{array}{l}\text { Create objec- } \\
\text { tive opinion; } \\
\text { independent } \\
\text { judgment; }\end{array}$ & $\begin{array}{l}\text { Involved in } \\
\text { board; not } \\
\text { a repre- } \\
\text { sentative of } \\
\text { the govern- } \\
\text { ment; }\end{array}$ & $\begin{array}{l}\text { Not serve as member of } \\
\text { managerial board; }\end{array}$ & $\begin{array}{l}\text { Increase } \\
\text { investor } \\
\text { confi- } \\
\text { dence; }\end{array}$ \\
\hline
\end{tabular}




\begin{tabular}{|c|c|c|c|c|c|}
\hline CFO & $\begin{array}{l}\text { Not men- } \\
\text { tioned } \\
\text { clearly in the } \\
\text { Code }\end{array}$ & $\begin{array}{l}\text { Not } \\
\text { mentioned } \\
\text { clearly in } \\
\text { the Code }\end{array}$ & $\begin{array}{l}\text { Not mentioned clearly in } \\
\text { the Code }\end{array}$ & $\begin{array}{l}\text { Not men- } \\
\text { tioned } \\
\text { clearly in } \\
\text { the Code }\end{array}$ & \\
\hline $\begin{array}{l}\text { Manage- } \\
\text { ment } \\
\text { team }\end{array}$ & $\begin{array}{l}\text { Have suf- } \\
\text { ficient time; } \\
\text { accountabil- } \\
\text { ity; }\end{array}$ & $\begin{array}{l}\text { terms and } \\
\text { contract } \\
\text { conditions } \\
\text { approved } \\
\text { by board; }\end{array}$ & $\begin{array}{l}\text { Present at shareholder } \\
\text { meeting; develop guide- } \\
\text { lines of operations; }\end{array}$ & $\begin{array}{l}\text { Not men- } \\
\text { tioned } \\
\text { clearly in } \\
\text { the Code }\end{array}$ & \\
\hline $\begin{array}{l}\text { Super- } \\
\text { visory } \\
\text { board }\end{array}$ & $\begin{array}{l}\text { Not men- } \\
\text { tioned } \\
\text { clearly in the } \\
\text { Code }\end{array}$ & $\begin{array}{l}\text { Not } \\
\text { mentioned } \\
\text { clearly in } \\
\text { the Code }\end{array}$ & $\begin{array}{l}\text { Not mentioned clearly in } \\
\text { the Code }\end{array}$ & $\begin{array}{l}\text { Not men- } \\
\text { tioned } \\
\text { clearly in } \\
\text { the Code }\end{array}$ & \\
\hline $\begin{array}{l}\text { Internal } \\
\text { control }\end{array}$ & $\begin{array}{l}\text { Independent } \\
\text { of executive } \\
\text { bodies; }\end{array}$ & $\begin{array}{l}\text { As control } \\
\text { over finan- } \\
\text { cial and } \\
\text { business } \\
\text { operation; }\end{array}$ & Approved by board; & $\begin{array}{l}\text { Mitigate } \\
\text { finan- } \\
\text { cial and } \\
\text { operating } \\
\text { risk; }\end{array}$ & \\
\hline $\begin{array}{l}\text { Internal } \\
\text { audit(IA) }\end{array}$ & $\begin{array}{l}\text { Not men- } \\
\text { tioned } \\
\text { clearly in the } \\
\text { Code }\end{array}$ & & $\begin{array}{l}\text { Efficient coordination with } \\
\text { EA; questioned by share- } \\
\text { holders; }\end{array}$ & & \\
\hline $\begin{array}{l}\text { External } \\
\text { audit(EA) }\end{array}$ & $\begin{array}{l}\text { Not } \\
\text { mentioned } \\
\text { clearly in the } \\
\text { Code }\end{array}$ & $\begin{array}{l}\text { Honesty, } \\
\text { compe- } \\
\text { tence; }\end{array}$ & $\begin{array}{l}\text { Efficient coordination with } \\
\text { IA; questioned by share- } \\
\text { holders; disclose deficien- } \\
\text { cies in financial activity; }\end{array}$ & $\begin{array}{l}\text { Not men- } \\
\text { tioned } \\
\text { clearly in } \\
\text { the Code }\end{array}$ & $\begin{array}{l}\text { From } \\
\text { the } \\
\text { code; }\end{array}$ \\
\hline $\begin{array}{l}\text { Disclo- } \\
\text { sure and } \\
\text { transpar- } \\
\text { ency }\end{array}$ & $\begin{array}{l}\text { Not men- } \\
\text { tioned } \\
\text { clearly in the } \\
\text { Code }\end{array}$ & $\begin{array}{l}\text { Insider } \\
\text { information } \\
\text { controlled } \\
\text { by the firm; }\end{array}$ & $\begin{array}{l}\text { Not allow operations } \\
\text { based on confidential } \\
\text { information; disclose in- } \\
\text { formation on independent } \\
\text { director; disclose share- } \\
\text { holders' information with } \\
20 \% \text { or }>5 \% \text { shares; }\end{array}$ & $\begin{array}{l}\text { Not men- } \\
\text { tioned } \\
\text { clearly in } \\
\text { the Code }\end{array}$ & \\
\hline $\begin{array}{l}\text { Share- } \\
\text { holders } \\
\text { and } \\
\text { Minor- } \\
\text { ity Stock- } \\
\text { holder }\end{array}$ & $\begin{array}{l}\text { Give objec- } \\
\text { tive opinion } \\
\text { in GM; meet- } \\
\text { ing agenda } \\
\text { clearly } \\
\text { defined; }\end{array}$ & $\begin{array}{l}\text { Equal treat- } \\
\text { ment for } \\
\text { those own } \\
\text { the same } \\
\text { shares; } \\
\text { receive } \\
\text { dividend } \\
\text { via bank } \\
\text { transfer; }\end{array}$ & $\begin{array}{l}\text { Not allow harm the rights } \\
\text { of other shareholders; } \\
\text { not misuse their rights; } \\
\text { presentation at meeting; } \\
\text { Exercise voting rights in a } \\
\text { simple way; }\end{array}$ & $\begin{array}{l}\text { Not men- } \\
\text { tioned } \\
\text { clearly in } \\
\text { the Code }\end{array}$ & \\
\hline
\end{tabular}




\begin{tabular}{|c|c|c|c|c|}
\hline $\begin{array}{l}\text { Financial } \\
\text { reporting } \\
\text { stand- } \\
\text { ards }\end{array}$ & $\begin{array}{l}\text { Not men- } \\
\text { tioned } \\
\text { clearly in the } \\
\text { Code }\end{array}$ & $\begin{array}{l}\text { Not } \\
\text { mentioned } \\
\text { clearly in } \\
\text { the Code }\end{array}$ & $\begin{array}{l}\text { Financial and business } \\
\text { plan approved by board; }\end{array}$ & $\begin{array}{l}\text { Protect } \\
\text { share- } \\
\text { holders' } \\
\text { capital } \\
\text { and firm } \\
\text { assets; }\end{array}$ \\
\hline $\begin{array}{l}\text { Employ- } \\
\text { ee }\end{array}$ & $\begin{array}{l}\text { Not men- } \\
\text { tioned } \\
\text { clearly in the } \\
\text { Code }\end{array}$ & $\begin{array}{l}\text { Not } \\
\text { mentioned } \\
\text { clearly in } \\
\text { the Code }\end{array}$ & $\begin{array}{l}\text { Workplace healthcare, } \\
\text { safety, labor efficiency } \\
\text { mentioned in ethical } \\
\text { standards; receive notes } \\
\text { on working conditions; }\end{array}$ & $\begin{array}{l}\text { Not men- } \\
\text { tioned } \\
\text { clearly in } \\
\text { the Code }\end{array}$ \\
\hline Note & \multicolumn{4}{|c|}{$\begin{array}{l}\text { The underlined part is describing some more works needed to be done for } \\
\text { relevant subjects and parties. }\end{array}$} \\
\hline
\end{tabular}

\section{The Establishment of a Relative Russian and North European Corporate Governance standards}

Comparison between the Russian, Norwegian and Finish Corporate Governance Principles

Different from other Codes, there is some information on the corporate assembly in the Norwegian Code 2010. For example, its composition has 12 members elected by shareholders and employee. Besides, the independence of Board members also involves the meaning in which family or business not affect his/her decisions.

On the other hand, the Finish Code considers many descriptive information of the firm need to be disclosed.

Besides, the Russian Code pays much attention to a qualified independent director. Generally, there are parts missing information in all 3 codes (see the above tables).

After making comparison, the following table is constructed in the way that creates the better understandable criteria, or at least a few.

Table D.4: A summary of A Relative Russian and North European Corporate Governance standards

\begin{tabular}{|l|l|l|}
\hline Subjects or parties & Main quality factors & Sub quality factors \\
\hline Audit committee & opinions on errors of busi- & $\begin{array}{l}\text { Unlimited access to firm informa- } \\
\text { ness and risks; Meeting at } \\
\text { lion; Meeting at least once a } \\
\text { month; }\end{array}$ \\
\hline
\end{tabular}




\begin{tabular}{|c|c|c|}
\hline CEO & $\begin{array}{l}\text { Day to day management; } \\
\text { Tasks may be delegated by } \\
\text { Board; }\end{array}$ & $\begin{array}{l}\text { Present at shareholder meeting; } \\
\text { resolve all corporate conflict mat- } \\
\text { ters not within authorities of BD; } \\
\text { Not the chairman of the board; }\end{array}$ \\
\hline The Chairman & $\begin{array}{l}\text { Professional reputation; } \\
\text { Perform a considerable } \\
\text { amount of job; Tasks may be } \\
\text { delegated by Board; }\end{array}$ & $\begin{array}{l}\text { organize work of committee; } \\
\text { nominating boar members for } \\
\text { committee; }\end{array}$ \\
\hline Corporate Secretary & $\begin{array}{l}\text { Knowledge for proper perfor- } \\
\text { mance and functions; not be } \\
\text { affiliated person of firm and } \\
\text { officers; }\end{array}$ & $\begin{array}{l}\text { receive notice from CEO, mana- } \\
\text { gerial board if any conflicts of } \\
\text { company interests; }\end{array}$ \\
\hline Compliance officer & $\begin{array}{l}\text { Not mentioned clearly in the } \\
\text { Code }\end{array}$ & $\begin{array}{l}\text { Not mentioned clearly in the } \\
\text { Code }\end{array}$ \\
\hline Board of Directors & $\begin{array}{l}\text { at least } 2 \text { directors independ- } \\
\text { ent of significant sharehold- } \\
\text { ers }\end{array}$ & $\begin{array}{l}\text { Set clear, predictable dividend } \\
\text { policy; have liability insurance; } \\
\text { not disclose insider information; }\end{array}$ \\
\hline $\begin{array}{l}\text { Independent direc- } \\
\text { tor }\end{array}$ & Involved in board; & $\begin{array}{l}\text { Not serve as member of manage- } \\
\text { rial board; not a representative of } \\
\text { the government; }\end{array}$ \\
\hline $\begin{array}{l}\text { Supervisory board to } \\
\text { the Management }\end{array}$ & Can be board of directors; & $\begin{array}{l}\text { Not mentioned clearly in the } \\
\text { Code }\end{array}$ \\
\hline $\begin{array}{l}\text { Supervisory to the } \\
\text { Board of Directors }\end{array}$ & $\begin{array}{l}\text { The corporate assembly } \\
\text { supervises the board and } \\
\text { executive management; }\end{array}$ & $\begin{array}{l}\text { Remuneration, composition } \\
\text { and operation disclosed; Use } \\
\text { independent expert in take-overs } \\
\text { valuation and explanation to } \\
\text { public; }\end{array}$ \\
\hline Internal control & $\begin{array}{l}\text { main features reviewed by } \\
\text { Audit Committee; Define } \\
\text { principles of internal control } \\
\text { and risk MGT; risk valued by } \\
\text { board; }\end{array}$ & $\begin{array}{l}\text { Risk MGT a part of internal con- } \\
\text { trol; annually reviewed by board } \\
\text { and on shortcomings; reviewed } \\
\text { by auditors with proposals for } \\
\text { improvement; }\end{array}$ \\
\hline Internal audit & $\begin{array}{l}\text { Monitored by audit commit- } \\
\text { tee; instructions approved by } \\
\text { audit committee; }\end{array}$ & Board receives routine report; \\
\hline External audit & $\begin{array}{l}\text { disclose deficiencies in finan- } \\
\text { cial activity; }\end{array}$ & $\begin{array}{l}\text { audit and non-audit service fees } \\
\text { disclosed; Honesty, competence; } \\
\text { once a year review internal con- } \\
\text { trol procedures; }\end{array}$ \\
\hline $\begin{array}{l}\text { Disclosure and trans- } \\
\text { parency }\end{array}$ & $\begin{array}{l}\text { Information published to } \\
\text { provide predictability to } \\
\text { shareholders; }\end{array}$ & $\begin{array}{l}\text { disclose shareholders' informa- } \\
\text { tion with } 20 \% \text { or }>5 \% \text { shares; }\end{array}$ \\
\hline
\end{tabular}




\begin{tabular}{|l|l|l|}
\hline Insider information & $\begin{array}{l}\text { Insider information con- } \\
\text { trolled by the firm; }\end{array}$ & $\begin{array}{l}\text { Not allow operations based on } \\
\text { confidential information; }\end{array}$ \\
\hline Shareholders & Give objective opinion in GM; & $\begin{array}{l}\text { Not allow harm the rights of } \\
\text { other shareholders; not misuse } \\
\text { their rights; }\end{array}$ \\
\hline Employee & $\begin{array}{l}\text { Workplace healthcare, safety, } \\
\text { labor efficiency mentioned in } \\
\text { ethical standards; }\end{array}$ & Their rights included in CSR; \\
\hline $\begin{array}{l}\text { Candidates in nomi- } \\
\text { nation }\end{array}$ & $\begin{array}{l}\text { Competence, capacity and } \\
\text { independence, education, } \\
\text { business experience; }\end{array}$ & $\begin{array}{l}\text { information given to sharehold- } \\
\text { ers before meeting; }\end{array}$ \\
\hline $\begin{array}{l}\text { The corporation as a } \\
\text { whole entity }\end{array}$ & $\begin{array}{l}\text { Define guidelines for CSR; } \\
\text { set corporate values; create } \\
\text { transparent mechanism for } \\
\text { dividend payment; }\end{array}$ & $\begin{array}{l}\text { Define scope of business, objec- } \\
\text { tives, strategies; appropriate eq- } \\
\text { uity for objectives, strategy, risk; }\end{array}$ \\
\hline The Code & $\begin{array}{l}\text { Have a separate corporate } \\
\text { governance statement; }\end{array}$ & "Comply or explain" approach \\
\hline
\end{tabular}

$<$ D.3> - The 1st Establishment of so-called Limited Russian and North European Corporate Governance Standards

Comparison of corporate governance standards between $<D .1>$ and $<$ D.2> group

Before we come to set up a set of general limited standards of corporate governance, we need to review the standards combined in the previous two (2) groups:

The advantages of Group 1, but not limited to, disclosure standards, shareholders and supervisory board, though it still works more on duties of corporate secretary.

On the contrary, the Group 2 including 3 above countries has certain strong features. For example, the Russian code considered the company as a whole which could establish the easy to understand dividend payment policy for shareholders. Whereas the Finnish Code 2010 needs the company issues its own CG statement on matters such as: information on managing directors and duties, etc...Generally, both groups need more information on Supervisory board to management.

Based on the above analysis, we consider building comparative standards as below. 
Table D.5: A summary of A Limited Russian and North European Corporate Governance standards

\begin{tabular}{|c|c|c|}
\hline Subjects or parties & Main quality factors & Sub quality factors \\
\hline Audit committee & $\begin{array}{l}\text { opinions on errors of busi- } \\
\text { ness and risks; Meeting at } \\
\text { least once a month; }\end{array}$ & $\begin{array}{l}\text { Vary depends on size, com- } \\
\text { plexity of the firm; }\end{array}$ \\
\hline $\begin{array}{l}\text { Nominating com- } \\
\text { mittee }\end{array}$ & $\begin{array}{l}\text { elect candidates not pro- } \\
\text { posed by board; use firm's } \\
\text { resources; }\end{array}$ & $\begin{array}{l}\text { Use external advisers to } \\
\text { find new directors; Can be } \\
\text { used for preparatory work } \\
\text { of the Board; }\end{array}$ \\
\hline $\begin{array}{l}\text { Numeration or } \\
\text { Compensation } \\
\text { Committee }\end{array}$ & $\begin{array}{l}\text { Remuneration reflects } \\
\text { boards' expertise, duties, } \\
\text { time; }\end{array}$ & $\begin{array}{l}\text { Attract skilled experts; } \\
\text { evaluate performance of BD } \\
\text { and managerial board; have } \\
\text { remuneration statement; }\end{array}$ \\
\hline CEO & $\begin{array}{l}\text { Present at shareholder } \\
\text { meeting; resolve all corpo- } \\
\text { rate conflict matters not } \\
\text { within authorities of } \mathrm{BD} ; \\
\text { Not the chairman of the } \\
\text { board; }\end{array}$ & $\begin{array}{l}\text { Day to day management; } \\
\text { Not in the nomination } \\
\text { committee; not be a Board } \\
\text { member; }\end{array}$ \\
\hline The Chair & $\begin{array}{l}\text { organize work of commit- } \\
\text { tee; nominating boar mem- } \\
\text { bers for committee; }\end{array}$ & $\begin{array}{l}\text { The Chair can be supported } \\
\text { by Vice Chairman; profes- } \\
\text { sional reputation; }\end{array}$ \\
\hline CEO \& The Chair & Roles can be combined; & $\begin{array}{l}\text { Tasks may be delegated by } \\
\text { Board; }\end{array}$ \\
\hline CFO & $\begin{array}{l}\text { Not mentioned clearly in } \\
\text { the Code }\end{array}$ & $\begin{array}{l}\text { Not mentioned clearly in } \\
\text { the Code }\end{array}$ \\
\hline $\begin{array}{l}\text { Corporate Secre- } \\
\text { tary }\end{array}$ & $\begin{array}{l}\text { Knowledge for proper } \\
\text { performance and functions; } \\
\text { not be affiliated person of } \\
\text { firm and officers; }\end{array}$ & $\begin{array}{l}\text { receive notice from CEO, } \\
\text { managerial board if any } \\
\text { conflicts of company inter- } \\
\text { ests; }\end{array}$ \\
\hline Compliance officer & $\begin{array}{l}\text { "Comply or explain" mecha- } \\
\text { nism; }\end{array}$ & Sound legal framework; \\
\hline Board of Directors & $\begin{array}{l}\text { Set clear, predictable divi- } \\
\text { dend policy; have liability } \\
\text { insurance; not disclose } \\
\text { insider information; } \\
\end{array}$ & $\begin{array}{l}\text { Two tier system; at least } 2 \\
\text { directors independent of } \\
\text { significant shareholders }\end{array}$ \\
\hline Management team & $\begin{array}{l}\text { develop guidelines of op- } \\
\text { erations; }\end{array}$ & Have sufficient time; \\
\hline
\end{tabular}




\begin{tabular}{|c|c|c|}
\hline $\begin{array}{l}\text { Independent direc- } \\
\text { tor }\end{array}$ & Involved in board; & $\begin{array}{l}\text { Not serve as member of } \\
\text { managerial board; not a } \\
\text { representative of the gov- } \\
\text { ernment; May from private } \\
\text { sector; }\end{array}$ \\
\hline $\begin{array}{l}\text { Supervisory board } \\
\text { to the Manage- } \\
\text { ment }\end{array}$ & Can be board of directors; & $\begin{array}{l}\text { Not mentioned clearly in } \\
\text { the Code }\end{array}$ \\
\hline $\begin{array}{l}\text { Supervisory to the } \\
\text { Board of Directors }\end{array}$ & $\begin{array}{l}\text { The corporate assembly } \\
\text { supervises the board and } \\
\text { executive management; } \\
\text { Can compose of govern- } \\
\text { ment authorities; }\end{array}$ & $\begin{array}{l}\text { Use independent expert in } \\
\text { take-overs valuation and } \\
\text { explanation to public; Can } \\
\text { be independent external } \\
\text { advisers; }\end{array}$ \\
\hline Internal control & $\begin{array}{l}\text { main features reviewed by } \\
\text { Audit Committee; Define } \\
\text { principles of internal con- } \\
\text { trol and risk MGT; }\end{array}$ & $\begin{array}{l}\text { annually reviewed by board } \\
\text { and on shortcomings; } \\
\text { reviewed by auditors with } \\
\text { proposals for improvement; }\end{array}$ \\
\hline Internal audit & $\begin{array}{l}\text { Monitored by audit com- } \\
\text { mittee; instructions ap- } \\
\text { proved by audit committee; }\end{array}$ & $\begin{array}{l}\text { Board receives routine } \\
\text { report; }\end{array}$ \\
\hline External audit & $\begin{array}{l}\text { disclose deficiencies in } \\
\text { financial activity; }\end{array}$ & $\begin{array}{l}\text { Avoid interest conflicts in } \\
\text { non-audit services; }\end{array}$ \\
\hline $\begin{array}{l}\text { Disclosure and } \\
\text { transparency }\end{array}$ & $\begin{array}{l}\text { How shareholders exercise } \\
\text { their control rights; }\end{array}$ & $\begin{array}{l}\text { Information published to } \\
\text { provide predictability to } \\
\text { shareholders; }\end{array}$ \\
\hline Insider information & $\begin{array}{l}\text { Insider information con- } \\
\text { trolled by the firm; }\end{array}$ & $\begin{array}{l}\text { Not allow operations based } \\
\text { on confidential information; }\end{array}$ \\
\hline Shareholders & $\begin{array}{l}\text { Participate effectively in } \\
\text { general meetings; }\end{array}$ & $\begin{array}{l}\text { Not allow harm the rights } \\
\text { of other shareholders; not } \\
\text { misuse their rights; }\end{array}$ \\
\hline Stakeholders & $\begin{array}{l}\text { Disclose shareholders' in- } \\
\text { formation with } 20 \% \text { or }>5 \% \\
\text { shares; }\end{array}$ & $\begin{array}{l}\text { Pay attention to Public } \\
\text { Company Act, Securities } \\
\text { trading Act, etc... }\end{array}$ \\
\hline Accountability & $\begin{array}{l}\text { Information equally avail- } \\
\text { able to all shareholders; }\end{array}$ & $\begin{array}{l}\text { disclose information on } \\
\text { independent director; }\end{array}$ \\
\hline $\begin{array}{l}\text { Financial reporting } \\
\text { standards }\end{array}$ & $\begin{array}{l}\text { In accordance with gener- } \\
\text { ally accepted accounting } \\
\text { standards and actual situ- } \\
\text { ation; }\end{array}$ & $\begin{array}{l}\text { Audited annually complied } \\
\text { with intl. or national stand- } \\
\text { ards; }\end{array}$ \\
\hline
\end{tabular}




\begin{tabular}{|l|l|l|}
\hline Leadership & $\begin{array}{l}\text { Board takes independent } \\
\text { leadership; }\end{array}$ & $\begin{array}{l}\text { CEO and Chairman in } \\
\text { charge; }\end{array}$ \\
\hline Employee & $\begin{array}{l}\text { Workplace healthcare, } \\
\text { safety, labor efficiency men- } \\
\text { tioned in ethical standards; } \\
\text { appropriately qualified and } \\
\text { well-trained; }\end{array}$ & $\begin{array}{l}\text { Follow ethical guidelines to } \\
\text { communicate with Board; }\end{array}$ \\
\hline $\begin{array}{l}\text { Candidates in } \\
\text { nomination }\end{array}$ & $\begin{array}{l}\text { Give information to } \\
\text { nominate a candidate for a } \\
\text { board on web; }\end{array}$ & $\begin{array}{l}\text { Competence, capacity and } \\
\text { independence, education, } \\
\text { business experience; }\end{array}$ \\
\hline $\begin{array}{l}\text { 3rd parties and } \\
\text { conflicts of inter- } \\
\text { ests }\end{array}$ & $\begin{array}{l}\text { avoid conflicts of interest } \\
\text { b.t candidates and board } \\
\text { members; }\end{array}$ & $\begin{array}{l}\text { Board members holding } \\
\text { some appointments note } \\
\text { conflicts of interest; }\end{array}$ \\
\hline $\begin{array}{l}\text { The corporation as } \\
\text { a whole entity }\end{array}$ & $\begin{array}{l}\text { Define guidelines for CSR; } \\
\text { set corporate values; }\end{array}$ & $\begin{array}{l}\text { Can have ethics committee; } \\
\text { Senior ethics officer; }\end{array}$ \\
\hline The Code & $\begin{array}{l}\text { Promote long term sustain- } \\
\text { ability of the enterprise; } \\
\text { clear and effective division } \\
\text { of roles and duties; }\end{array}$ & $\begin{array}{l}\text { Have a separate corporate } \\
\text { governance statement; } \\
\text { "Comply or explain" ap- } \\
\text { proach }\end{array}$ \\
\hline
\end{tabular}

\section{Conclusions}

In efforts to prevent failures and control the corporate governance issues after crisis, the 2006 UN Code and the 2008 SWF Governance Principles were formed. Both Codes describes many aspects of disclosure.

As analyzed, the UN Code gives more information on committees and supervisory boards.

On the other side, SWF Code has a detailed description of recommendations to risk management in investment field.

On the other hand, in group 2, the Norwegian Code 2010 pays attention to take-overs and relevant duties of corporate employee. The Russian Code gives more information on corporate secretary roles.

In general, both Codes of 2 groups promote long term sustainable value for the corporation and emphasize roles of audit committee and internal control.

In consideration of corporate governance issues analyzed in the previous sessions, we proposed the main and sub quality factors in this paper a set of general limited Russian and North European corporate governance 
standards in a limited global model with selected 2 above groups of Codes. It has some implications for further research and proper recommendations to relevant government and organizations.

\section{Suggestion for developing countries including Viet Nam}

The above incorporated standards need to be re-evaluated before any organization in emerging markets including Viet Nam wants to use them for their own operation. It means that these standards are flexible, not strict. And they have to pay attention to quality factors relating to employee, management, and the company.

\section{Acknowledgement}

This is a special time to thank you all respected people who directly or indirectly help me to complete this paper:

- My family, teachers, colleagues, parents and brother Dinh T.N.Hien

- Board of Directors at Banking University, HCMC

- My Professors at International U of Japan, Niigata, Japan - Amos Tuck school of Business, USA and Arhus business school, Denmark

- Editors and friends

\section{References}

[1] Abdullah, Haslinda., and Valentine, Benedict., (2009), Fundamental and Ethics Theories of Corporate Governance, Middle Eastern and Finance Economics, Issue 4;

[2] Alexander, David., (2010), Corporate Governance and Earnings Management : Going Beyond Agency Theory and Secondary Data, Intl. Journal of Corporate Governance, Vol.2, No.1;

[3] Cheung, Stephen Y.L., Chan, Bob Y., (2004), Corporate Governance in Asia, AsiaPacific Development Journal, Vol.11, No.2;

[4] Joo, Thomas W., (2010), Theories and Models of Corporate Governance, UC Davis Legal Studies Research Paper, No.213;

[5] OECD Corporate Governance Guidelines, OECD, 1999;

[6] Lashgari, Malek., (2004), Corporate Governance: Theory and Practice, The Journal of American Academy of Business;

[7] Shin, Jogn Seop., Kim, Soo Wook., and Kim, Hyun Jung., (2012), Governance Change and Its Impact on Board Decision Making, Intl. Journal of Corporate Governance, Vol.3, No.1; 
[8] Lim, Lenici., (2010), Corporate Governance - A Survey of Australian and South East Asian Systems, Corporate Governance eJournal, Bond University;

[9] Wei-An, Li., (2008), Corporate Governance in China - Research and Evaluation, John Wiley \& Sons , Inc.;

[10] www.thecorporatelibrary.com;

[11] www.fic.wharton.upenn.edu;

[12] www.chanrobles.com/secmemorandumcircularnoo22002.html. 